\title{
TELL ME MORE: A CONTENT ANALYSIS OF EXPANDED AUDITOR REPORTING IN THE UNITED KINGDOM
}

\author{
A Dissertation \\ by \\ KECIA WILLIAMS SMITH \\ Submitted to the Office of Graduate and Professional Studies of \\ Texas A\&M University \\ in partial fulfillment of the requirements for the degree of \\ DOCTOR OF PHILOSOPHY
}

\begin{abstract}
Chair of Committee, Dechun Wang
Committee Members, Sarah Rice

Christopher Wolfe

Deidra Schleicher

Head of Department, James Benjamin
\end{abstract}

August 2016

Major Subject: Accounting

Copyright 2016 Kecia Williams Smith 


\begin{abstract}
This study examines the effect of expanded audit disclosures required by ISA 700 (UK and Ireland), The Independent Auditor's Report on Financial Statements, on the communication value of the audit report. The new ISA 700 audit report is the first attempt by an auditing standard-setter to include expanded auditor disclosure in the audit report. The expanded disclosures significantly alter the pass/fail audit report model; however, it is not immediately clear that more audit report disclosures improve communication value.

I address whether communication value improves in the post-ISA 700 by handcollecting audit report content and demographic data from premium-listed London Stock Exchange and Irish Stock Exchange listed companies. Using content analysis measures, readability and tone, as proxies for communication value, I find that in the post-ISA 700 period: 1) audit report readability improves and 2) audit report tone changes with a higher occurrence of negative and uncertain words. I also evaluate analyst behavior in response to the ISA 700 audit report. I find that analyst following and analyst forecast dispersion decrease in the post-ISA 700 period. In additional analyses, I show that Big N and industry expert auditors write audit reports that are more readable. I also find that domain-specific word dictionaries, generated from Form-10Ks and earnings press releases, have a lower frequency in audit reports in both the pre and post ISA 700 period.

With the heightened global interest in improving the historical pass/fail audit report, these results show that expanded audit disclosures can be communicated in a manner that is accessible and meaningful to the financial statement user.
\end{abstract}




\section{DEDICATION}

To the fortitude of Sallie Clanton Thomas, the faith of Ruth Thomas Williams, and the future of Kanaan Hamilton Smith. 


\section{ACKNOWLEDGEMENTS}

I thank my dissertation committee, Dechun Wang (Chair), Sarah Rice, Chris Wolfe, and Deidra Schleicher for their guidance and support throughout this research process. I am thankful for the support of my fellow Ph.D students at Texas A\&M University and members of the PhD Project Accounting Doctoral Student Association during my matriculation. I am especially grateful for the camaraderie and friendship of my fellow classmate, Erik Lewis Beardsley.

I appreciate the insights on the expanded audit report from senior audit practitioners in the United Kingdom that were integral to my research process. I thank Colin Chapman for his assistance in collecting the UK annual reports used in this study. I gratefully acknowledge generous financial support from Texas A\&M University, Mays Business School, AICPA Foundation, and KPMG Foundation.

I extend my deepest gratitude to the great "cloud of witnesses" that have provided their unyielding support of my academic endeavors. I am grateful for the leadership of Dean Emeritus Quiester Craig and the accounting faculty at North Carolina A\&T State University for providing the initial spark of intellectual curiosity that led me to pursue my doctorate in accounting. I also appreciate the vision of Bernie Milano to increase the number of minority professors in business schools. I will always treasure the advice and wisdom shared by countless mentors, counselors, and friends that kept me on the path to completion. I will endeavor to pay these kindnesses forward to future accounting academics. Finally, I am forever indebted to my family who shared in this journey with me. To God be the glory for the marvelous things He has done. 


\section{TABLE OF CONTENTS}

Page

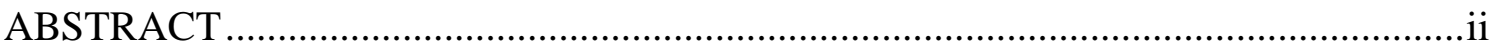

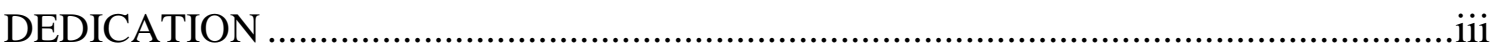

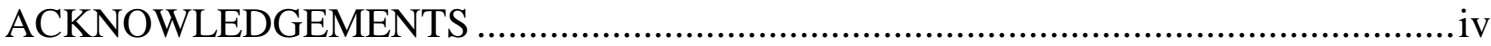

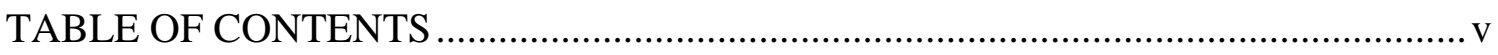

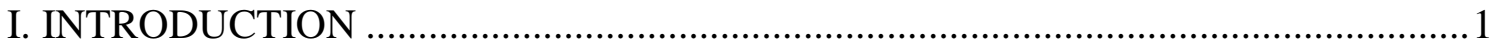

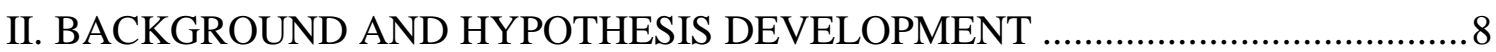

The Auditor's Report on the Financial Statements (ISA 700) ............................... 8

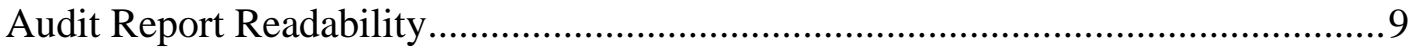

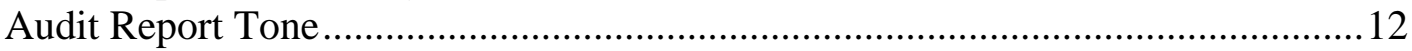

ISA 700 Audit Report and Analyst Behavior.................................................. 14

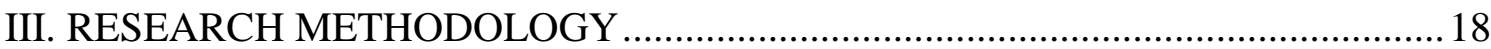

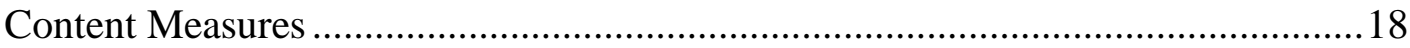

ISA 700 Implementation and Audit Report Readability (H1a) ............................20

ISA 700 Implementation and Audit Report Tone (H1b) ....................................21

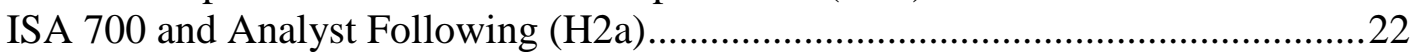

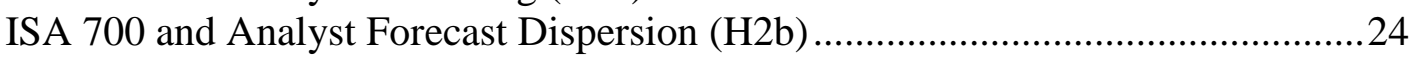

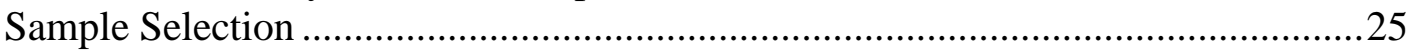

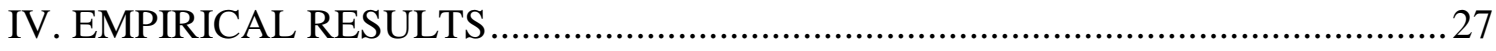

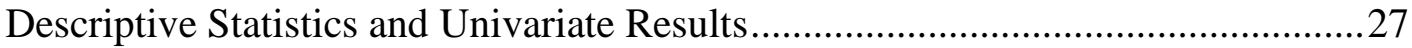

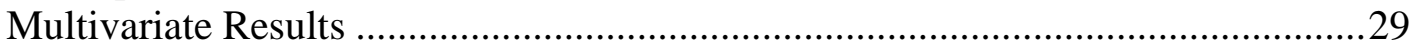

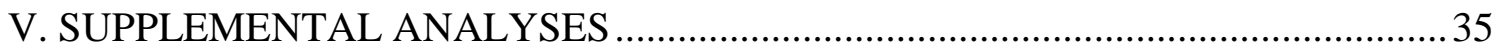

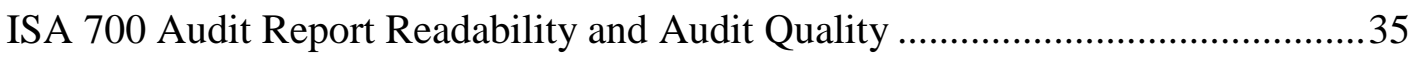

ISA 700 Audit Report Readability and Audit Firms ............................................ 38

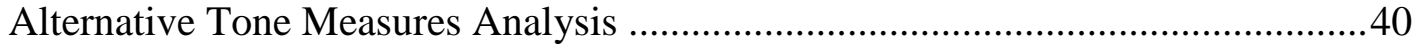

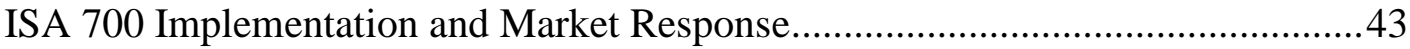

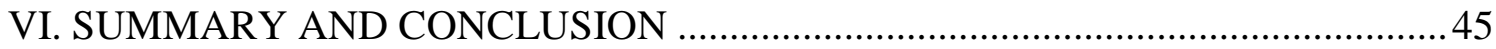




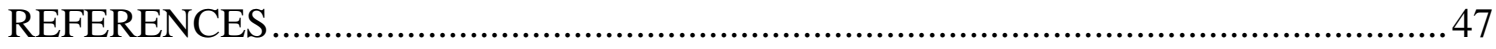

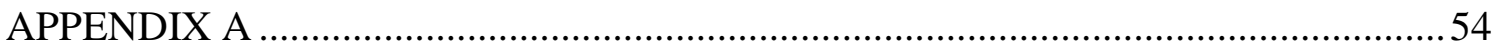

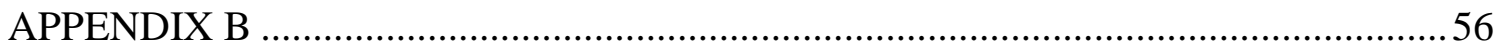

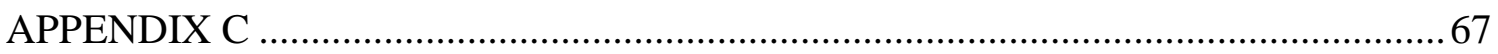




\section{INTRODUCTION}

Communicating the results of financial statement audits has evolved from the two-paragraph report (AIA 1948; APC 1980) to the more recent multi-paragraph audit report (FRC 1993; AICPA 1988; PCAOB 2007). One mainstay in the evolution of the audit report is the standardized language that provides a uniform description of the audit process. ${ }^{1}$ To address the criticism on the opaque audit reports that are dominated by boilerplate language, the United Kingdom (UK) Financial Reporting Council (FRC) issued International Standard on Auditing (UK and Ireland) 700, The Independent Auditor's Report on Financial Statements (“ISA 700”) in June 2013 (FRC 2013a). ISA 700 requires audit reports, for issuers that comply with the UK Corporate Governance Code, to include a discussion of: 1) the risks of material misstatements with the greatest impact on engagement team effort; 2) the application of materiality in the audit; and 3) the scoping decisions made in the execution of the audit. The standard suggests that in order for the audit report to be useful to investors, the additional disclosures should be client-specific and not general or standardized (FRC 2013a). ${ }^{2}$ The new ISA 700 audit report is the first attempt by a standard-setter to include expanded auditor disclosure in the audit report. The expanded disclosures significantly alter the pass/fail audit report

\footnotetext{
${ }^{1}$ In response to the Northern Rock bank failure, John Griffith-Jones, former UK KPMG Chief Executive Officer commented, "If you have a company that has leverage of 100 times and a company that has no leverage at all, the audit report is the same"(Osborne 2011). This view highlights the challenge of the historical pass/fail model of the standard audit report which prompted standard-setters to consult with constituents to determine the best path forward to enhance the communication value of the standard audit report (FRC 2007; IAASB 2011; PCAOB 2010; PCAOB 2013; PCAOB 2014; FRC 2013c).

2 The UK Corporate Governance Code ("Code"), maintained by the FRC, provides principles and rules for boards of UK listed companies. The Code is located here: https://www.frc.org.uk/Our-Work/Codes-Standards/Corporategovernance/UK-Corporate-Governance-Code.aspx .
} 
model; however, it is not immediately clear that more audit report disclosures improve communication value. Using the introduction of ISA 700 as a quasi-natural experiment, I examine whether the communication value of the audit report changes after the issuance of ISA 700.

Communication value in financial reporting is evident when the information provided by the source is received by the destination (Smith and Smith 1971). Coram, Mock, Turner, and Gray (2011) provide a similar definition when examining audit reports and note that communication value is shown when the message that is intended to be conveyed by the report is received by the intended user (Coram et al. 2011). I use two content measures, readability and tone, as proxies for communication value. Readability is a communication measure that captures whether the receiver can understand the message delivered by the sender. If the receiver understands the message, then the message is useful to the receiver thereby improving the communication value of the message. Tone is a measure that captures the "affect or feeling of a communication" (Henry 2008). If the audit report reflects the tone of the audit engagement, as expressed in the choice of words used in describing the audit, the receiver's understanding is improved thereby enhancing communication value. To assess the financial statement users' response to ISA 700, I investigate the change in analyst behavior under the new reporting regime. If the expanded audit report has increased in communication value, then analyst behavior should change, signaling an improvement in the information environment. 
Evaluating the communication value of ISA 700 is important because it provides empirical evidence on whether the standard achieved its objective of enhancing communication between the auditor and the financial statement user. As the UK is the first jurisdiction to require client-specific audit disclosure, assessing the communication value of the expanded audit report will benefit other standard-setters considering or adopting similar proposals (PCAOB 2013; PCAOB 2016; IAASB 2015). Prior studies have shown the difficulty financial statement users have in understanding the information in audit reports (Church et al. 2008; Gray et al. 2011; Coram et al. 2011; Asare and Wright 2012; Manson and Zaman 2001; Hermanson et al. 1991). Academic research shows that the standard audit report did not convey financial risks during the financial crisis as the majority of the failed financial institutions received unqualified opinions prior to failing (Doogar et al. 2015; Sikka 2009). The introduction of ISA 700 provides a tailored approach for auditors to convey information that can enhance financial statement users' understanding of the audit process. The additional disclosures on risks of material misstatements, materiality, and audit scope give users insights into the auditor's decision process during the audit. Thus, consistent with the standard setters' objective, I predict that the communication value of audit reports under ISA 700 regime increases.

I address this important issue by examining audit report readability and audit report tone. First, I adopt the method proposed by Smith and Smith (1971) and Li (2008) in evaluating the communication effectiveness of financial reports by measuring readability. Readability measures have been used in evaluating disclosures and 
accounting narratives (Beattie 2014; Li 2010; Jones and Shoemaker 1994), however there is limited research on audit report readability (Barnett and Loeffler 1979; Pound 1981; Smith and Smith 1971). Previous studies on audit report readability performed in the late 1970's are prior to the issuance of Statement of Auditing Standard No. 58, Reports on Audited Financial Statements (AICPA 1988) and the audit market consolidation of early 1990s. I address this gap in the literature by comparing the readability of the newly introduced ISA 700 audit report to the pre-ISA 700 report using a sample of publicly traded firms from the UK and Ireland.

Second, I assess whether audit report tone changes in the post-ISA 700 period compared to the pre-ISA 700 period. Accounting and finance literatures have introduced evaluating tone as an approach to further understand the impact of the written word on investor behavior (Antweiler and Frank 2004; Tetlock 2007; Tetlock et al. 2008; Loughran and McDonald 2011). Historically, the audit report included legalistic and boilerplate language used in every audit report regardless of the underlying risks of the audit client. With the ISA 700 report, the language used is auditor-generated which can give additional insights into the nature of the communication to the user. I utilize financial word dictionaries developed by Loughran and McDonald (2011) to measure the tone of the expanded audit report. By comparing audit report tone in the pre-ISA 700 and post-ISA 700 periods, I assess whether the auditor issues reports consistent with the FRC's expectation to reduce general and boilerplate language.

Lastly, I investigate whether financial statement users respond to the expanded audit report. Focusing on a subset of financial statement users, I test the association 
between ISA 700 and two sell-side analyst behaviors: analyst following and analyst forecast dispersion. Assessing analyst following provides insight into analyst effort when the information environment changes. Evaluating analyst forecast dispersion determines whether the expanded audit report improves the information environment. When evaluating annual report readability, Lehavy, Li, and Merkley (2011) show that less readable Form 10-Ks are associated with greater analyst following and greater forecast dispersion (Lehavy et al. 2011). However, it is an empirical question whether analysts respond similarly when the auditor is the source of the communication.

Using hand-collected audit report data from London and Irish Stock Exchange listed companies, I find that readability improves in the post-ISA 700 period. This finding supports that ISA 700 meets the objective of improving the value of the audit report to the financial statement user. I also find that the expanded audit report captures more client-specific audit risk with increases in negative and uncertain tone. This finding rebuts criticisms that the new audit report includes boilerplate language that is not useful to the reader (IAASB 2011; Mock et al. 2013; Gray et al. 2011; Citi Research 2014a). Finally, I find that analyst behavior changes in the post-ISA 700 period as evidenced by lower analyst following and lower analyst forecast dispersion. In addition, less readable audit reports are associated with higher analyst following and higher analyst forecast dispersion in both the pre- and post-ISA 700 periods, consistent with Lehavy et al. (2011). In supplemental analyses, I find that audit report readability and audit report tone are associated with high quality auditor characteristics. I also find that domain-specific word dictionaries, generated from Form-10Ks and earnings press 
releases, have a lower frequency in audit reports in both the pre and post ISA 700 period suggesting that auditor disclosure is different from management disclosure.

My study makes several important contributions. First, I add to the readability literature by expanding the readability of annual reports to audit reports. Recent reviews on the auditor's reporting model and archival audit research (Mock et al. 2013; DeFond and Zhang 2014) and initial studies on the US expanded audit report proposal (Christensen et al. 2014; Kachelmeier et al. 2014) illustrate the need for more research on standard-setting related to the audit report. ISA 700 introduces several additional disclosures related to risk assessment, materiality, and audit scope designed to enhance the communication between the auditor and financial statement user. Using this setting, my paper is the first to examine audit report readability in the current environment. My results show that these additional disclosures are useful when the disclosures effectively transmit the information that the auditor intended.

Second, I provide insight that is useful to standard-setters and regulators. The International Auditing and Assurance Standards Board (IAASB) released guidance on expanded auditor reporting in January 2015 (IAASB 2015) and the Public Company Accounting Oversight Board (PCAOB) is currently deliberating expanding the audit report in the United States (PCAOB 2013; PCAOB 2016). This study informs standardsetters and regulators on how audit firms implemented ISA 700 in the United Kingdom and the response from financial statement users. These findings could influence future standard-setting in this area. I show that the audit report is more readable in the postISA 700 period, which improves the communication value. I also show that analysts 
respond to the ISA 700 audit report, which confirms earlier analysts' preferences for client-specific information in the report.

Finally, I expand the audit literature with the introduction of content measures to evaluate the effectiveness of the expanded audit report. More specifically, unlike concurrent studies (Gutierrez et al. 2016; Lennox et al. 2015; Reid et al. 2015) that use a year dichotomous variable to compare the audit report information content in the preversus post-ISA 700 era, I use readability to evaluate how well the ISA 700 report communicates its message to the user. In addition, I use audit report tone to assess what the auditor is communicating in the expanded report. I also examine domain-specific word lists in the context of auditor disclosure to investigate word choice differences in auditor disclosure versus management disclosure. Overall, my test results show the benefit of using content measures in the evaluation of the auditor communication.

The next section of the paper provides an overview of ISA 700, reviews prior literature, and develops my hypotheses. Section 3 discusses research methodology. Section 4 discusses results. Section 5 includes supplemental analyses. Section 6 summarizes and concludes. 


\section{BACKGROUND AND HYPOTHESIS DEVELOPMENT}

\section{The Auditor's Report on the Financial Statements (ISA 700)}

The UK Financial Reporting Council issued ISA 700 (UK and Ireland), The Auditor's Report on the Financial Statements in June 2013. This standard requires audit report disclosures that describe: 1) the risks of material misstatement that required the greatest audit effort; 2) the application of materiality in the execution of the audit; and 3) the scope of the audit including how the engagement team addressed (1) and (2). The standard is applicable for entities subject to UK Corporate Governance Code and is effective for fiscal periods beginning on or after October 1, 2012 (FRC 2013a). ${ }^{3}$ The introduction of ISA 700 (UK and Ireland) in June 2013 was the first major content change for the audit report in several decades. In the press release announcing the issuance of the standard, Nick Land, Chairman of the FRC's Audit and Assurance Council, commented, "The provision of a fuller description of the work the auditor has undertaken will give far more insight to investors than the binary pass/fail model of the current audit report (FRC 2013b).”

The introduction of ISA 700 provides a unique opportunity for auditors to discuss audit risk areas and audit scoping determinations. The standard addresses the critiques of the historical pass/fail model audit report by requiring client-specific audit risk information in the report. The standard provides suggestions for items to disclose

\footnotetext{
${ }^{3}$ Entities subject to UK Corporate Governance Code reporting are companies with a Premium listing of equity shares on the London Stock Exchange and companies incorporated in Ireland with a primary or secondary equity listing on the Ireland Stock Exchange. The London Stock Exchange designates Premium listing for companies and investment entities that issue equity securities and comply with the UK super-equivalent governance requirements.
} 
such as the materiality type (overall, performance, and threshold for audit committee communication), audit coverage by area, locations visited by the auditor, and the audit group structure (centralized or multi-location). The standard also states the FRC's preference for client-specific language instead of "standardized language" when applying the provisions of ISA 700 (FRC 2013a).

\section{Audit Report Readability}

\section{Communication Value, Communication Theory, and the Audit Report}

The audit report in its simplest form is a communication from the auditor to financial statement users about the results of the audit. Figure 1 shows the audit report communication model based on the linear communication model advanced by Shannon and Weaver (Shannon and Weaver 1949). Academic research on the communication value of the audit report has noted both an expectations gap and an information gap when assessing the communication value of the audit report. The expectations gap is the gap between what the auditor's responsibility is and what financial statement users believe the auditor's responsibility should be. The information gap is a different, but related concern, wherein there is a gap between information that is publicly available to the financial statement user and information that is not publicly available, that the financial statement user believes will be helpful in investment decision-making (IAASB 2011). An abundance of research on the expectations gap has resulted in mixed results on whether the changes to the audit report introduced by standard-setters have reduced the expectations gap (Mock et al. 2013; Church et al. 2008; Gray et al. 2011; Coram et al. 2011; Turner et al. 2010; Geiger 1994; Miller et al. 1990; Miller et al. 1993). 
Research on the information gap is limited, but survey evidence shows that financial statement users prefer more information in the audit report to assist with understanding their underlying investments (IAASB 2011; IOSCO 2009; CFA Institute 2010).

Smith and Smith (1971) advance the importance of communication theory when assessing how well financial reporting delivers its message to the financial statement users. In their study, they introduce readability as an approach to evaluate the effectiveness of financial reporting communication. Using a sample of fifty financial statements notes, they find that the notes are understandable to readers with at least a college education, highlighting the complexity of the documents. They contend that readability is an adequate measure to evaluate the performance of how well financial reporting communicates its message about the client (Smith and Smith 1971). Other studies show similar findings that financial statement communication is very complex when evaluating management reports (Lewis et al. 1986), footnote disclosure (Barnett and Loeffler 1979), corporate annual reports (Soper and Dolphin 1964; Jones and Shoemaker 1994; Clatworthy and Jones 2001; Courtis 1998; Courtis 1995; Li 2008) and analyst reports (De Franco et al. 2015).

Calculating readability is an approach to evaluate the performance of how well an audit report communicates its message about the audit process and the audited entity. There are limited studies that evaluate the readability of audit reports. Barnett and Loeffler (1979) find that the audit report readability is "very difficult." In addition, they found no statistically significant difference in readability between the external auditors issuing the audit report. Pound (1981) finds for a sample of Australian audit reports 
that the reading ease is "inhibitive" to effectively communicating audit results to financial statement users. Consistent with Barnett and Loeffler (1979), Pound did not find a difference in reading ease among the large public accounting firms. Taken together, these studies show that the audit report is inherently difficult to understand and that there is an opportunity to improve the communication value of the audit report. ISA 700, Communication Value, and Readability

Leading to the issuance of ISA 700 (UK and Ireland), standard-setters discussed readability (FRC 2007; ICAEW 2007). However, most of the discussion centered on moving standardized audit scope language later in the report or to a separate website (FRC 2007). As noted in Smith and Smith (1971), "communication occurs in financial reporting only if the meanings intended by the information source are assigned to the financial statement messages by the destination." As previously established, readability is a measure that can assess how well information is communicated (Smith and Smith 1971; Courtis 1998; Courtis 1995; Li 2008; Beattie 2014). Therefore, it is an empirical question whether ISA 700, with its additional disclosure requirements, improves the readability of the audit report. Readability could improve as the auditor has the flexibility to comply with the provisions of ISA 700. If the auditor views the expanded audit report as a communication to the financial statement user and not a compliance exercise, the auditor may be more inclined to communicate in a way that is easier for the recipient to understand. As such, the readability of the audit report may improve with the implementation of ISA 700. 
In informal discussions with UK audit practitioners from several international accounting firms, I noted a consistent theme of making the additional disclosures beneficial to the reader. Specifically, one senior practitioner commented that there was a focus to "make the [audit report] as readable as possible." Another practitioner commented that their firm "tried to stay away from jargon terms, [wanted to make the report] easy to follow." If the auditor acts with a communication focus versus a compliance focus when implementing ISA 700, the auditor will create an audit report that is more readable than the pre-ISA 700 audit report. As such, I state my first hypothesis in the alternative:

H1a: Audit report readability improves in the post-ISA 700
audit report period compared to the pre-ISA 700 audit
report period.

\section{Audit Report Tone}

Critics of the expanded audit report raised concerns regarding the potential for boilerplate disclosures that provided limited information to the user (IAASB 2011; Mock et al. 2013; Gray et al. 2011; Citi Research 2014a). Readability measures how well a financial reporting message conveys its intended audience but it does not fully capture what the message contains. Recent accounting and finance literature has introduced content analysis to provide insights on whether the content of business texts is related to investor behavior (Antweiler and Frank 2004; Tetlock 2007; Tetlock et al. 2008; Loughran and McDonald 2011). One commonly used content analysis measure is tone, 
wherein tone captures the "affect" or "feeling" (Henry 2008) of Form 10-Ks, business press articles, and investor informal chat discussions ${ }^{4}$.

Prior to the issuance of ISA 700, the need for an evaluation of audit report tone was non-existent as all audit reports contained the same boilerplate language. With ISA 700 , there is an opportunity to examine the feeling communicated based on the words used as reflected in tone measures. I use Loughran \& McDonald's (2011) Negative, Positive, and Uncertainty word dictionaries to capture the audit report tone. These three word dictionaries are more appropriate in the audit report setting as the negative and uncertainty word dictionaries approximate the level of negative or risk-related content discussed in the audit report. The positive word dictionary used in this setting captures the alternative word choice to negative or uncertain language. ISA 700 requires auditors to disclose risks of material misstatements that the engagement team dedicated significant effort to and to disclose the material and scoping decisions related to those risk assessments. In informal discussion with audit partners on the implementation of ISA 700, they remarked that firms did not overly rely on standard audit report templates and allowed audit partners to tailor the audit report based on the underlying client-risks. One interviewee stated that the firm stressed that "this [audit report] is your communication; you need to be proud of what you have done." As auditors have the

\footnotetext{
${ }^{4}$ Tone is commonly determined based on the word count frequency of words in psychology-developed word lists, such as the Harvard General Inquirer word list, found in the business texts (Loughran and McDonald 2011; Henry and Leone 2016). Loughran \& McDonald (2011) provide an alternative to the psychology-based categorizations by creating six word dictionaries specific to financial statement disclosure (negative, positive, uncertainty, litigation, strong, and weak). I do not use the litigation word dictionary due to the significant overlap with the negative word dictionary. In addition, I do not use the strong and weak dictionaries due to low rates of occurrence. Several studies in accounting and finance have used these dictionaries when examining short-selling (Engelberg et al. 2012), local news and firm value (Gurun and Butler 2012), and disclosure tone and shareholder litigation (Rogers et al. 2011).
} 
ability to expand their word usage in the post-ISA 700 environment, I expect the expanded audit report to include more word variety that captures risks than in the prior standard audit report. This leads me to my next hypothesis:

H1b: $\quad$ The frequency of negative, positive, and uncertain words (i.e., audit report tone) will be higher in the post-ISA 700 period than in the pre-ISA 700 period.

\section{ISA 700 Audit Report and Analyst Behavior}

Financial Analysts and the Audit Report

The aforementioned audit report communication model illustrates three components in the communication process: 1) the auditor, 2) the audit report, and 3) the financial statement user. To assess the communication value of the expanded audit report, it is necessary to determine if the financial statement user receives the audit report message. Financial statement users include a broad constituency including investors, financial analysts, banks, and regulators. Of these users, financial analysts are sophisticated consumers of financial information. The financial analyst performs an "information intermediary" role in the capital market by reducing the information asymmetry between management and the investor (Healy and Palepu 2001).

The audit report is a source of information for financial analysts when performing their information intermediary role. Prior research shows that analysts value the unqualified opinion included in the audit report (Coram et al. 2011; Mock et al. 2009). In an experiment with Australian financial analysts, Coram et al. (2011) show that analysts focus on the opinion but not on the remaining audit report content. Mock et al. (2009) conducted focus groups with users, including financial analysts, to obtain user 
perceptions on the standard audit report. Their results show that financial analysts desire "more information and transparency" in the audit report (Mock et al. 2009). An analyst participating in the focus group commented that "in addition to the company's disclosure of how they selected specific estimates and their judgments, analysts also would like a similar discussion from the auditor (Mock et al. 2009).” The CFA Institute, a professional association of investment professionals, issued a 2010 survey in which $94 \%$ of the respondents liked to see more information in the standard audit report (CFA Institute 2010). In addition, survey research on sell-side and buy-side analysts show that financial reports are an input to the forecasting process (Brown et al. 2015; Brown et al. 2014). In summary, prior research illustrates the analysts' use of the audit report and preference for additional information in the audit report. Following prior studies, I examine two analyst behaviors, analyst following and analyst forecast dispersion, to capture changes in analyst effort and changes in the information environment in the postISA 700 period.

ISA 700 Audit Report and Analyst Following

Bloomfield (2002) shows that complex financial information is harder to process by investors because of the high information processing costs expended to identify relevant information (Bloomfield 2002). Following this theory, Lehavy et al. (2011) suggest that for less readable documents, analysts can provide a service to the investor by following the company and extracting the relevant information thereby reducing the investors' information processing costs. Therefore, following the logic in their findings, less readable audit report communication and lower frequency of tone words in audit 
report provide more opportunity for analysts to provide intermediary services in processing complex information. This in turn results in higher analyst following. Alternatively, if the information processing costs for opaque (i.e., less readable) communication are too high, the analyst may choose not to provide their services resulting in a decrease in analyst following (Lehavy et al. 2011).

Although prior literature shows that less readable disclosures are associated with greater analyst following when examining annual report readability, it is unclear how analyst following will change in the expanded audit report setting. The expanded audit reports may be more readable and contain tone words that better represent audit risk, but may not change the information processing costs as the reports may convey what the analyst already knows about client risks. This would result in no change in analyst following in the post-ISA period. Alternatively, the expanded audit report may provide additional information to the investors in a manner that alters the need for an information intermediary. As such, analyst following may change in the post-ISA 700 period. Due to these competing predictions, I state my next hypothesis in the null:

H2a: Analyst following does not change in the post-ISA 700 period. ISA 700 Audit Report and Analyst Forecast Dispersion

Analyst forecast dispersion captures the variation in the views of analysts in their forecasts for a company. Analysts use private information along with publicly disclosed financial information to inform their earnings forecast. With each financial analyst having differing information sets and differing abilities to forecast, variation in the earnings forecasts occurs. Prior literature shows the less readable communication 
contributes to higher analyst forecast dispersion due to the high cost of processing and interpretation (Lehavy et al. 2011). ISA 700 audit reports include client-specific audit disclosures available to all financial analysts for use in forecasting earnings. The availability of these disclosures in terms of more readability and higher frequency of words representing audit risk (i.e. tone) could reduce the cost of processing the information, but the effect on the interpretation could differ. On one hand, audit reports in the post-ISA 700 period could result in analysts interpreting the client-risks in a consistent manner due to the ease of information processing. This results in more consistency with other analyst forecasts leading to reduced forecast dispersion. On the other hand, audit reports in the post-ISA 700 period could result in analysts generating divergent views due to the revelation of new information or due to differences in interpretations of the new disclosures. This leads to the same or increased forecast dispersion in the post-ISA 700 period compared to the pre-ISA 700 period. Due to these competing predictions, I state my next hypothesis in the null:

H2b: Analyst forecast dispersion does not change in the post-ISA 700 period. 


\section{RESEARCH METHODOLOGY}

\section{Content Measures}

Readability Measure

Consistent with readability studies (Li 2008; De Franco et al. 2015; Smith and Smith 1971), I use $F O G$ as the primary readability measure to compare the pre-ISA 700 audit reports to the post-ISA 700 audit reports. ${ }^{5}$ The Fog Index $(F O G)$ is a widely used readability statistic developed by Robert Gunning (Gunning 1952) that evaluates the number of words in a sentence and the percentage of complex words (words with three syllables or more) to estimate the number of formal years of education an average person would need to read and comprehend the text. ${ }^{6}$ The higher the measure the more complex the text.

$$
F O G=(\text { words per sentence }+ \text { percent of complex words) } x 0.4 \text {. }
$$

To calculate $F O G$ for each company-year observation, I obtain all annual reports for the companies, extract the audit report, and convert all documents to text files. I remove all header and pagination information from the text file to result in text-only

\footnotetext{
${ }^{5}$ Flesch-Kincaid (KINCAID) and Flesch (FLESCH) Reading Ease are additional readability measures. The FleschKincaid (KINCAID) Index calculates readability based on syllables per word and words per sentence and rates the text based on the U.S. grade school level. The higher the measure the more education is required to read the text. It is calculated as: $(11.8 \mathrm{x}$ syllables per word $)+(0.39 \mathrm{x}$ words per sentence $)-15.59$. Flesch (FLESCH) Reading Ease rates reading ease on a scale of 1 to 100 based on words per sentence and syllables per sentence. Contrary to FOG and KINCAID, the higher the number, the easier the text is to read. FLESCH is calculated as: $206.8-(1.015 \mathrm{x}$ words per sentence $)-(84.6 \mathrm{x}$ syllables per word $)$. The empirical results and inferences using these measures are consistent with the FOG measures and are untabulated.

${ }^{6}$ I do not perform tests using other measures of readability such as file size (Loughran and McDonald 2014) and BOG (Bonsall et al. 2015) as these measures are focused on compliance with US Securities and Exchange Commission rules on Plain English usage and are not fully applicable in the UK reporting setting.
} 
opinion. Using Perl (Lingua::EN::Fathom package), I calculate FOG for each firm-year observation. ${ }^{7}$

Tone Measures

Tone is commonly determined based on a "bag of words" approach using the frequency of words in psychology-developed word lists, such as the Harvard General Inquirer word list, appearing in business texts (Loughran and McDonald 2011; Henry and Leone 2016). The word frequencies are utilized to quantify the tone exhibited in the written texts. Loughran \& McDonald (2011) provide an alternative to the psychologybased lists by creating six word dictionaries specific to financial statement disclosure (negative, positive, uncertainty, litigation, strong, and weak).

I obtain the Negative, Positive, Uncertainty word lists from Bill McDonald's Word List Page maintained at http://www3.nd.edu/ mcdonald/Word_Lists.html. The latest Master Word List (Dictionary) is as of March 2015. There are 2,355 words included in the Negative word list, 354 words included in the Positive word list, and 297 words included in the Uncertainty word list. I converted the word lists to column vectors that include word and dummy variables that correspond to the designated word list for each word. Due to the overlap in the Negative and Uncertain word lists, several words included more than one dummy variable. After the column vectors were completed, I imported the matrix into the Linguistic Inquiry and Word Count (LIWC)

\footnotetext{
${ }^{7}$ In other readability studies (Li 2008; De Franco et al. 2015), length is used to capture another facet of readability and is calculated as the logarithmic transformation of the number of words in the text. In my setting, the audit report length mechanically increases due to the additional disclosures required by ISA 700. As such, length is not a readability measure in this study.
} 
Software as a custom dictionary. Using the custom dictionary function, LIWC analyzed each audit report in the sample to generate the NEGATIVE, POSITIVE, and

UNCERTAIN tone measures. The measures represent the word count frequency for the negative, positive, and uncertain word lists that appear in the sample audit reports.

\section{ISA 700 Implementation and Audit Report Readability (H1a)}

Prior readability models used by Li (2008) focus on client-specific variables when evaluating MD\&A disclosure developed by client management. Audit reports are a product of both client characteristics and auditor characteristics. I expand the $\mathrm{Li}$ (2008) model to include auditor characteristics (Hronsky 1998) that may impact the level of auditor disclosure in the audit opinion. In addition, I control for the audit report structure. The following model tests the association between ISA 700 implementation and audit report readability. I use a differences approach where each firm serves as its own control using one observation from the pre-ISA 700 period and one observation from the post-ISA 700 period.

$$
\begin{aligned}
& \text { FOG } \quad=\beta_{0}+\beta_{1} \text { NEWOPINION }{ }_{i t}+\beta_{2} \text { SIZE }_{i t}+\beta_{3} M_{i t} \\
& +\beta_{4} A G E_{i t}+\beta_{5} S I_{i t}+\beta_{6} E A R N_{-} V O L_{i t}+\beta_{7} N B S E G_{i t} \\
& +\beta_{8} \text { ACQUISITION }_{i t}+\beta_{9} \text { SEO }_{i t}+\beta_{10} \text { BIGN }_{i t} \\
& +\beta_{11} \text { COMBINED_OP } i t+\text { Industry Effects }+\varepsilon
\end{aligned}
$$

NEWOPINION, the variable of interest, is an indicator variable equal to one if the audit opinion is issued in the first year of ISA 700 implementation and zero otherwise (the year immediately prior to ISA 700 implementation). I control for client characteristics and auditor characteristics that may alter the level of auditor disclosure in the auditor's opinion. Larger firms ( $S I Z E)$, high market-to-book firms $(M B)$, firms with special items $(S I)$, firms with earnings volatility $\left(E A R N_{-} V O L\right)$, firms with multiple business segments 
(NBSEG), firms that are acquisitive (ACQUISITION), firms that issue equity offerings $(S E O)$, and firms with a combined audit opinion (COMBINED_OP) are more likely to have complicated audit opinions. Older firms $(A G E)$ and Big $\mathrm{N}$ firms $(B I G N)$ are less likely to have complicated audit opinions. Industry fixed effects are included to control for industry variation. Variable descriptions are included in Appendix A.

\section{ISA 700 Implementation and Audit Report Tone (H1b)}

To test the association between the implementation of ISA 700 and the tone of the audit report, I modify the readability model in Equation 2 to include tone measures (NEGATIVE, POSITIVE, and UNCERTAIN) as the dependent variables. I also include a composite tone measure, $C O M B I N E D \_T O N E$, to capture the overall change in word usage by summing NEGATIVE, POSITIVE, and UNCERTAIN for each observation. I include the same control variables in the tone model as in the readability model as the same client and auditor specific characteristics that drive the complexity of an audit report also drive the tone of the audit report. The following model tests the association between ISA 700 implementation and audit report tone.

TONE

$$
\begin{aligned}
& =\beta_{0}+\beta_{1} \text { NEWOPINION }_{i t}+\beta_{2} \text { SIZE }_{i t}+\beta_{3} M B_{i t} \\
& +\beta_{4} A G E_{i t}+\beta_{5} S_{i t}+\beta_{6} E A R N_{-} V O L_{i t}+\beta_{7} N B S E G_{i t} \\
& +\beta_{8} \text { ACQUISITION }+\beta_{9} S E O_{i t}+\beta_{10} \text { BIGN }_{i t} \\
& +\beta_{11} \text { COMBINED_OP } \\
& \text { it }+ \text { Industry Effects }+\varepsilon
\end{aligned}
$$

NEWOPINION, the variable of interest, is an indicator variable equal to one if the audit opinion is issued in the first year of ISA 700 implementation and zero otherwise (the year immediately prior to ISA 700 implementation). Consistent with Equation 2, I 
include industry fixed effects to control for industry variation. All other variable descriptions are consistent with Equation 2 and are included in Appendix A.

\section{ISA 700 and Analyst Following (H2a)}

To test the association between ISA 700 implementation and analyst following, I follow prior literature (Bhushan 1989; Marston 1997; Lehavy et al. 2011). Equation 4 tests the association between ISA 700 implementation and analyst following. Equation 5 tests the association between audit report readability (tone) and analyst following. Equation 6 tests the interactive effect of ISA 700 implementation and audit report readability (tone) on analyst following.

$$
\begin{aligned}
& \text { FOLLOWING } \quad=\beta_{0}+\beta_{1} \text { NEWOPINION } i t+\beta_{2} \text { LOGSIZE }_{i t}+\beta_{3} \text { MB }_{i t} \\
& +\beta_{4} N B S E G_{i t}+\beta_{5} I N S T_{i t}+\beta_{6} R_{i t}+\beta_{7} E A R N_{-} V O L_{i t} \\
& +\beta_{8} \text { CROSS_LIST } T_{i t}+\beta_{9} \log \text { FILESIZE } E_{i t}+\text { Industry Effects } \\
& +\varepsilon \\
& \text { FOLLOWING } \quad=\beta_{0}+\beta_{1} \text { FOG }(\text { TONE })_{i t}+\beta_{2} L O G S I Z E_{i t}+\beta_{3} M B_{i t} \\
& +\beta_{4} N B S E G_{i t}+\beta_{5} I N S T_{i t}+\beta_{6} R_{i t}+\beta_{7} E A R N_{-} V O L_{i t} \\
& +\beta_{8} \text { CROSS_LIST } T_{i t}+\beta_{9} \log \text { FILESIZE } E_{i t}+\text { Industry Effects } \\
& +\varepsilon \\
& \left.+\beta_{3} \text { NEWOP*FOG (NEWOP*TONE) }\right)_{i t}+\beta_{4} \text { LOGSIZE }_{i t} \\
& +\beta_{5} M B_{i t}+\beta_{6} N B S E G_{i t}+\beta_{7} I N S T_{i t}+\beta_{8} R D_{i t}+\beta_{9} E A R N_{-} V O L_{i t} \\
& +\beta_{10} \text { CROSS_LIST } T_{i t}+\beta_{11} \log \text { FILESIZE } E_{i t}+\text { Industry Effects } \\
& +\varepsilon
\end{aligned}
$$

Consistent with prior literature (Lehavy et al. 2011; O'Brien and Bhushan 1990;

Brennan and Subrahmanyam 1995), FOLLOWING is calculated as the number of 
analysts included in the first consensus forecast estimate after audit report issuance. ${ }^{8}$

NEWOPINION is the variable of interest in Equation 4 and FOG (TONE) is the variable of interest in Equation 5. The interaction term, $N E W O P^{*} F O G$ (NEWOP*TONE), is the variable of interest in Equation 6. I control for client characteristics that are associated with analyst following found in prior literature. Lehavy et al. (2011), Bhushan (1989), O'Brien and Bhushan (1990), and Marston (1997) find that larger firms (LOGSIZE) have greater analyst following. As a proxy for growth (Lehavy et al. 2011), I use the logarithm of book to market firms $(M B)$. To control for firm complexity (Lehavy et al. 2011; Marston 1997) that may lead to higher analyst following, I include the natural logarithm of the firm's business segments (NBSEG). Institutional ownership is associated with high analyst following, therefore I control for institutional ownership (INST) (Bhushan 1989; Brennan and Subrahmanyam 1995; Frankel et al. 2006). I also control for high research and development expense (RD) (Barth et al. 2001), volatile earnings (EARN_VOL) (Lehavy et al. 2011), and UK firms cross-listed in the US (CROSS_LIST) (Marston 1997). Finally, I control for the content of the audit report using the logarithmic transformation of the electronic file size of the audit report

\footnotetext{
${ }^{8}$ The United Kingdom Listing Authority Disclosure and Transparency (DTR) Rule 6.4 requires all issuers to issue audited annual reports within four months of the fiscal period end. The audited annual report includes the audit report. Per DTR 6.3, the issuer must provide a public announcement of the availability of the audited annual report using a regulatory information service (i.e., London Stock Exchange Regulatory News Service (RNS)) and file the announcement with the National Storage Mechanism (NSM). I hand-collect the annual report announcement dates from NSM for each firm-year in my sample. For the limited number of observations where the announcement date was not clearly determined, I obtained the audit report release date from Bloomberg. DTR 6.3 is located here: https://www.handbook.fca.org.uk/handbook/DTR/6/3.html . NMS is located here: http://www.morningstar.co.uk/uk/NSM .
} 
(logFILESIZE). Industry fixed effects are included to control for industry variation. Variable descriptions are included in Appendix A.

\section{ISA 700 and Analyst Forecast Dispersion (H2b)}

To test the association between the implementation of ISA 700 and analyst forecast dispersion, I follow Lehavy et al. (2011). Equation 7 tests the association between the implementation of ISA 700 and analyst forecast dispersion. Equation 8 tests the association between analyst forecast dispersion and audit report readability (tone) and the ISA 700 period. Equation 9 tests the interactive effect of ISA 700 implementation and audit report readability (tone) on analyst forecast dispersion.

$$
\begin{aligned}
& \text { DISPERSION } \quad=\beta_{0}+\beta_{1} \text { NEWOPINION } i t+\beta_{2} \text { LOGSIZE }_{i t}+\beta_{3} M B_{i t} \\
& +\beta_{4} N B S E G_{i t}+\beta_{5} I N S T_{i t}+\beta_{6} R D_{i t}+\beta_{7} E A R N_{-} V O L_{i t} \\
& +\beta_{8} \log \text { FILESIZE } E_{i t}+\text { Industry Effects }+\varepsilon \\
& \text { DISPERSION } \quad=\beta_{0}+\beta_{1} \text { FOG }(\text { TONE })_{i t}+\beta_{2} \text { LOGSIZE }_{i t}+\beta_{3} M B_{i t} \\
& +\beta_{4} N B S E G_{i t}+\beta_{5} I N S T_{i t}+\beta_{6} R D_{i t}+\beta_{7} E A R N_{-} V O L_{i t} \\
& +\beta_{8} \log \text { FILESIZE }{ }_{i t}+\text { Industry Effects }+\varepsilon \\
& \text { DISPERSION } \quad=\beta_{0}+\beta_{1} \text { NEWOPINION }{ }_{i t}+\beta_{2} \text { FOG }(\text { TONE })_{i t} \\
& +\beta_{3} N E W O \beta^{*} F O G(N E W O P * T O N E)_{i t} \\
& +\beta_{4} L_{O G S I Z E_{i t}}+\beta_{5} M B_{i t}+\beta_{6} N B S E G_{i t}+\beta_{7} I N S T_{i t} \\
& +\beta_{8} R D_{i t}+\beta_{9} E_{A R N_{-} V O L_{i t}}+\beta_{10} \log \text { FILESIZE }{ }_{i t} \\
& + \text { Industry Effects }+\varepsilon
\end{aligned}
$$

Consistent with Lehavy et al. (2011), DISPERSION is defined as the standard deviation of the individual analyst earnings per share forecasts in the first analyst consensus forecast (annual) after audit report issuance, scaled by the share price 90 days prior to the consensus forecast date. NEWOPINION is the variable of interest in Equation 7 and FOG (TONE) is the variable of interest in Equation 8. NEWOP*FOG (NEWOP*TONE) 
is the variable of interest in Equation 9. Consistent with Equations 4-6, I control for client characteristics are associated with analyst forecasts. Industry fixed effects are included to control for industry variation. Variable descriptions are included in Appendix A.

\section{Sample Selection}

The study sample is comprised of companies listed on the London Stock Exchange (LSE) and Irish Stock Exchange (ISE) that are required to comply with the provisions of ISA 700. I start with all companies listed in the Compustat Global Fundamentals Annual Dataset listed on the London Stock Exchange or Irish Stock Exchange from 2012 - 2014. From those firms, I eliminate firm-year observations prior to the year immediately before ISA 700 implementation and firms that are not Premium listed based on the December 31, 2013 LSE Company Listing. ${ }^{9}$ In addition, I eliminate financial institutions and investment funds based on the London Stock Exchange Securities Groups. I obtain financial information and securities identifying information from the Compustat Global Fundamental Annual and Security Daily Datasets. This results in 458 companies eligible for the readability analysis.

I obtain audit reports for the pre-ISA 700 and post-ISA 700 periods for each company identified to generate readability statistics. I eliminate 30 companies in which readability statistics are not determinable due to language translation or file security issues. Subsequently, I match the Compustat Global and readability data to the Bureau

\footnotetext{
${ }^{9}$ The listing of LSE companies and securities are located at http://www.londonstockexchange.com/statistics/companies-and-issuers/companies-and-issuers.htm .
} 
van Dijk Amadeus (Financials) Dataset to obtain closing share price, market capitalization, and shares outstanding for each firm-year observation. I obtain institutional ownership information from Bloomberg and analyst information from the I/B/E/S International Summary Statistics File. Audit firm information is hand collected from company annual reports for each company in the sample. The resulting sample size is 350 companies and 700 company-year observations. Table 1 presents the sample size calculation for this study. 


\section{EMPIRICAL RESULTS}

\section{Descriptive Statistics and Univariate Results}

Table 2 presents descriptive statistics for the study sample. By design, fifty percent of the sample audit reports are subject to the provisions of ISA 700

(NEWOPINION). The mean FOG value of 27.35 indicates that the audit report remains a complicated text when compared to other business texts such as Form 10-Ks $(\mathrm{FOG}=19.39)$ and Wall Street Journal articles $(\mathrm{FOG}=15.20)(\mathrm{Li} 2008)$. The tone measures for the sample show that $1.24 \%$ (NEGATIVE) of the words in the audit report are included in the negative word lists. Only $0.25 \%$ (POSITIVE) of the words in the audit reports are included in the positive word lists and $0.87 \%$ (UNCERTAIN) of the words in the audit reports are included in the uncertainty word lists. The NEGATIVE tone measure is consistent with Loughran and McDonald's negative tone of $1.39 \%$ when assessing Form 10-Ks (Loughran and McDonald 2011). However, the measures for POSITIVE and UNCERTAIN are lower for my audit report sample than for Form 10-K samples noted in the finance literature. The mean analyst following (FOLLOWING) is approximately 11 analysts and the mean forecast dispersion (DISPERSION) is 0.30 .

Audit firm related descriptive statistics show that the four largest international accounting firms $(B I G N)$ audit $93 \%$ of the sample. Seventy-five percent (BUSY) of the audits occur during the months of December - March. Sixty-nine percent (COMBINED_OP) of the audit reports include the report for both the group and the 
parent company. ${ }^{10}$ The natural logarithm of audit fees for the sample is 13.00

(LOGFEES). These audit firms descriptive statistics show that the companies subject to ISA 700 are primarily clients of the Big $\mathrm{N}$ firms and the audit work is concentrated in the traditional audit year-end work periods. ${ }^{11}$ London audit firm offices issue fifty-five percent $(L O N D O N)$ of the sample audit opinions. Client specific descriptive statistics show that 19\% (FTSE 100) and 39\% (FTSE250) of the company-year observations are for companies listed on the Financial Times Stock Exchange (FTSE) Index 100 and 250 for the entire sample period, respectively. The average size of the companies in the sample is 20.49 (SIZE) and the average age of the company is approximately 24 years. The market-to-book ratio is $2.41(M B)$ and only $16 \%$ (LOSS) are loss firms. Two percent (GOING CONCERN) of the sample audit opinions have going concern report modifications. Approximately one-third (EXP_DOMINANCE) of the sample are audited by firms that are industry leaders. Overall, the client statistics show that the sample is comprised of mature companies that are fiscally healthy. All continuous variables have been winsorized at the $1^{\text {st }}$ and $99^{\text {th }}$ percentiles to account for outliers in the sample.

Table 3 includes the results of the univariate analysis that compares test variables in the pre-ISA 700 period to the post-ISA 700 period. The results show that readability

\footnotetext{
${ }^{10}$ In the United Kingdom, the corporate structure includes the group and the parent company. In most cases, the operations of the company are recorded in the group accounts with the holding company operations in the parent company.

${ }^{11}$ I evaluate readability measures on an audit firm basis. In untabulated results, BDO and KPMG have the lowest average FOG measures at 26.22 and 26.56, respectively. PWC, which has the highest number of observations in our sample, has an average $F O G$ of 27.55. OTHER, which represents the smallest firms in our sample, have an average $F O G$ of 28.10. Overall, this provides support that there is variation in audit report content across firms.
} 
(FOG) showed statistically significant improvement in the Post-ISA 700 period. FOG decreased 4.83 points $(\mathrm{p}<0.01)$. This result provides initial support that the expanded audit report improved in readability, which then enhances the usefulness of the report to the financial statement reader. Similarly, all tone measures increased in the Post-ISA 700 period with NEGATIVE showing the highest increase with an increase of 0.87 . Untabulated results show that the majority of the client characteristics variables did not have a statistically significant change in the post-ISA 700 period from the pre-ISA 700 period. $M B$ increased slightly and more firms had acquisition activity (ACQUISITION). In addition, more firms combined the parent company audit report with the group audit report in the post-ISA 700 period. Related to the audit report, the number of pages increased in the Post-ISA 700 period to 3.34 pages from 1.23 pages in the pre-ISA 700 period. On average, auditors included approximately four risks in the ISA 700 audit report. The analyst behavior variables, FOLLOWING and DISPERSION, showed decreases in the post-ISA 700 period, but the differences are not statistically significant. The multivariate analyses that follow further explore these univariate results.

\section{Multivariate Results}

Hypothesis 1 a

Hypothesis 1a evaluates the association between readability and the implementation of ISA 700. Table 4 presents the ordinary least squares regression results of estimating Equation 2. The variable of interest, NEWOPINION, is negative and significant $(\mathrm{p}<0.01)$. The coefficient of $(-4.99)$ shows that an average person would need five fewer years of formal education to read and comprehend the audit report in the 
post-ISA 700 period. This indicates that in the post-ISA 700 report period audit report complexity decreased resulting in a more readable report. Said differently, the improvement in readability shows that the overall communication value has improved in the expanded audit report. The coefficients on the firm-specific control variables are not statistically different from zero except the positive coefficients on $B I G N(\mathrm{p}<0.10)$ and COMBINED_OP $(\mathrm{p}<0.01)$. This indicates that a change in client-level factors did not have an effect on how the auditors disclosed audit risks, materiality, and audit scope decisions. The change in readability is consistent with UK practitioners' views that the new standard was the impetus for generating reports that were easy to understand.

These results support H1a and show strong evidence that audit reports under ISA 700 are more readable to users thereby achieving the intended purpose of ISA 700 of improving communication value of the report.

Hypothesis $1 b$

Hypothesis $1 \mathrm{~b}$ tests the association between the implementation of ISA 700 and audit report tone. Table 5 presents the result of the ordinary least squares regression of Equation 3. Column 1 shows that the variable of interest, NEWOPINION, is positive and significant $(\mathrm{p}<0.01)$ when NEGATIVE is the dependent variable. This indicates that the tone of the post-ISA 700 report is more negative than in the prior period. This is consistent with auditors including risks of material misstatements and the impact of the risks on the scope of the audit. Large firms $(B I G N)$ generated reports that had higher negative language evidenced by the positive and significant coefficient $(\mathrm{p}<0.01)$. Interestingly, clients with special items ( $S I)$, segments (NBSEG), and combined opinions 
(COMBINED_OP) have less negative language in their audit opinions. These areas would potentially generate additional disclosures but may have written in a manner that fewer negative terms were included.

Column 2 includes the results when POSITIVE is the dependent variable. Again, the variable of interest is positive and significant $(\mathrm{p}<0.01)$, however the magnitude of the coefficient NEWOPINION is much smaller than the coefficients when NEGATIVE and UNCERTAIN are the dependent variables. Larger clients (SIZE) have a statistically significant association with positive language in the audit report. Large firms $(B I G N)$ have a higher occurrence of positive language in their audit report. Firms with volatile earnings ( $\left.E A R N_{-} V O L\right)$ had fewer occurrences of positive language in their audit reports. The results from Column 2 indicate that in the post-ISA 700 period, auditors included positive language in the expanded audit report but at a lower frequency.

Column 3 provides results when UNCERTAIN is the dependent variable. Consistent with both Columns 1 and 2, the variable of interest, NEWOPINION, is positive and significant $(\mathrm{p}<0.01)$ when evaluating the presence of uncertain language. Large firms $(S I Z E)$ have a higher occurrence of uncertain language $(\mathrm{p}<0.01)$ while $S I$, $E A R N_{-} V O L$, and $C O M B I N E D \_O P$ remain negative and significant $(\mathrm{p}<0.01)$. Evaluating the composite tone measure, COMBINED_TONE, the coefficient on NEWOPINION is positive and significant $(\mathrm{p}<0.01)$ indicating that in the post-ISA 700 period there is a higher rate of occurrence for tone-related words. Overall, the results provide evidence the audit report tone did increase in the post-ISA 700 period supporting H1b. The results refute the argument that the additional disclosures in ISA 700 would 
be boilerplate in nature and highlight the benefit of the auditor language choice in disclosure.

Hypothesis $2 a$

Hypothesis $2 \mathrm{a}$ tests the association between analyst following and the implementation of ISA 700. Table 6 presents the ordinary least squares regressions of Equations 4-6. Column 1 shows that the coefficient on NEWOPINION is negative and significant $(-0.65, \mathrm{p}<0.01)$. This indicates that the change in the information environment may have resulted in analysts reallocating their efforts away in following specific companies. This is consistent with the view that less complicated documents require fewer services of an information intermediary to reduce the informationprocessing costs for investors. However, the average number of analysts following is fewer by less than one analyst. The reduction is equivalent to $5.9 \%$ given the average analysts following of 11 .

Consistent with prior literature, Column 2 shows that the coefficient on FOG is positive and significant $(\mathrm{p}<0.01)$. Similar to the findings when evaluating annual report readability (Lehavy et al. 2011), less readable audit reports are associated with higher analyst following. The coefficients on LOGSIZE, INST, and EARN_VOL are positive and significant $(\mathrm{p}<0.01)$ in both Columns 1 and 2 providing evidence that firm size, institutional ownership and earnings volatility contribute to a higher analyst following. ${ }^{12}$

\footnotetext{
${ }^{12}$ In untabulated tests, I conduct the same analysis for Equations 4 and 5 using the number of analyst following immediately prior to the earnings announcement to capture any variation in forecast timing. In these tests, NEWOPINION is negative and significant $(\mathrm{p}<0.01)$ and $F O G$ is positive and significant $(\mathrm{p}<0.01)$. These results and inferences are consistent with the findings in Table 6.
} 
When evaluating the interactive effect of audit report readability in the post-ISA 700 period in Column 3, the main effect of $N E W O P I N I O N$ remains negative and significant at the $\mathrm{p}<0.10$ level. The main effect of $F O G$ remains positive and significant at the $\mathrm{p}<0.10$ level; however, the interaction, $N E W O P^{*} F O G$, is not statistically significant. ${ }^{13}$

Column 4 reports a negative but insignificant coefficient $(\mathrm{p}>0.10)$ on COMBINED_TONE. Column 5 reports positive but insignificant coefficients $(\mathrm{p}>0.10)$ on NEWOP*TONE and COMBINED_TONE. Taken together, these results show that in the post-ISA 700 period the content measures are not associated with analyst following. Hypothesis $2 b$

Hypothesis $2 \mathrm{~b}$ tests the association between analyst forecast dispersion and the implementation of ISA 700. Table 7 presents the results of the ordinary least squares regressions of Equations 7-9. Column 1 reports a negative and marginally significant coefficient on NEWOPINION $(\mathrm{p}<0.10)$, supporting $\mathrm{H} 2 \mathrm{~b}$. These results indicate that the introduction of client-specific audit disclosures in the ISA 700 report assisted in reducing the variation between analysts when developing their forecasts. The public dissemination of audit risks and audit scoping decisions provides all analysts with similar information to use in their forecasts. The availability of previously private information has a leveling effect on the analyst forecasts resulting in reduced dispersion.

In Column 2, the coefficient on $F O G$ is positive and significant $(\mathrm{p}<0.05)$. This indicates that less readable audit reports contribute to higher analyst dispersion. A less

\footnotetext{
13 To address collinearity in the interaction models, FOG (TONE) is mean-centered when the interaction term is included in Equation 6.
} 
readable audit report is subject to more interpretation by the analyst covering the client and results in wider forecast dispersion. Consistent with prior literature, the number of segments, institutional ownership, and research and development expenditures are positive and significant $(\mathrm{p}<0.10)$. Overall, the results show that analyst behavior responded to the ISA 700 required disclosures. This validates the analysts' position that a more informative audit report is beneficial to their role as financial statement users. In the interaction model, $N E W O P^{*} F O G$ is negative and significant $(\mathrm{p}<0.10)$ indicating that FOG is less associated with analyst dispersion in the post-ISA 700 period. ${ }^{14}$

In Columns 4 and 5, the coefficients on COMBINED_TONE are negative but insignificant ( $\mathrm{p}>0.10)$. The coefficient on NEWOP*TONE in Column 5 is positive and insignificant. These results indicate that the variation effect of tone is diminished in the post-ISA 700 period.

\footnotetext{
14 To address collinearity in the interaction models, FOG $(T O N E)$ is mean-centered when the interaction term is included in Equation 6.
} 


\section{SUPPLEMENTAL ANALYSES}

\section{ISA 700 Audit Report Readability and Audit Quality}

In November 2006, the FRC issued a discussion paper entitled "Promoting Audit Quality" that introduced an audit quality framework that included four main drivers of audit quality, which included the "reliability and usefulness of audit reporting (FRC 2006)." Linking communication theory to the FRC audit quality framework, more readable audit reports are more useful reports, which contributes to higher audit quality. This logic is consistent with practitioner feedback on the implementation of ISA 700, that the expanded audit report is a "positive driver of audit quality."

Thus, auditor characteristics such as auditor size and office size that are associated with higher audit quality, may contribute to differential readability in audit reports. The auditing literature has shown that Big $\mathrm{N}$ firms exhibit higher audit quality

than non-Big N firms due to their size and access to resources (Defond et al. 2014; Choi et al. 2010; DeAngelo 1981; Dopuch and Simunic 1982). Studies using office size show that larger offices perform higher quality audits than smaller offices when evaluating earnings quality (Francis and Yu 2009; Choi et al. 2010) and restatements (Francis et al. 2013) because larger offices possess a higher level of independence from their clients and expertise. As such, it is possible that the audit quality benefits embedded in large auditors and large practice offices shown in the financial reporting setting will extend to the audit report readability setting.

Auditor expertise is another auditor characteristic that may lead to differences in ISA 700 audit report readability. Prior literature shows that national-level and city-level 
industry experts provide higher quality audits (Reichelt and Wang 2010) and that there is an audit fee premium for industry experts (Ferguson et al. 2003; Francis et al. 2005). Balsam, Krishnan, and Yang (2003) also find that clients of audit industry specialists have better earnings quality than clients of non-audit industry specialists (Balsam et al. 2003). If the auditor is an industry expert, they may be well versed in the industry and can communicate their understanding of the client's business in an easy to read manner. Alternatively, the industry expert may resort to using industry jargon and terminology when discussing significant audit matters that may limit the readability of the audit report even when providing higher quality audits.

While ISA 700 is applicable for any auditors of premium listed companies on the London Stock Exchange or a listed company on the Ireland Stock Exchange (FRC 2013a), auditors are not equally equipped to apply this new standard. Barclays' Audit Committee Member Mike Ashley, stated that "the big four accountancies have fared well but [said] the next tier of firms had been slower to react (Pearce 2014).” This comment provides additional motivation for understanding implementation differences between Big $\mathrm{N}$ firms and non-Big $\mathrm{N}$ firms, between large and small practice offices, and between industry experts and non-experts.

The following model tests the association between auditor characteristics and audit report readability in the post-ISA 700 period.

$$
\begin{aligned}
& \text { FOG }=\beta_{0}+\beta_{1}(\text { Auditor Characteristics })+\beta_{2} S I Z E_{i t}+\beta_{3} M B_{i t}+\beta_{4} A G E_{i t} \\
& +\beta_{5} S_{i t}+\beta_{6} E A R N_{-} V O L_{i t}+\beta_{7} N B S E G_{i t}+\beta_{8} \text { ACQUISITION }{ }_{i t} \\
& +\beta_{9} S E O_{i t}+\beta_{10} \text { COMBINED_OP }{ }_{i t}+\text { Industry Effects }+\varepsilon
\end{aligned}
$$


I evaluate three auditor characteristics, Big N firm affiliation, industry expertise, and office size and their association with audit report readability. BIGN is an indicator variable equal to one if the auditor is one of the big four international accounting firms. Industry expertise is captured using two measures based on the number of clients audited by the firm in a specific SIC Code (one-digit). EXP_NUMCLT is equal to one if the company is audited by an audit firm with the most clients in that industry when compared to all other audit firms in the sample in year $t$ and zero otherwise. EXP_DOMINANCE is equal to one if the company is audited by an audit firm that has $10 \%$ more audit clients in an industry than the firm's nearest competitor in year $\mathrm{t}$ and zero otherwise. OFFICE_SIZE equals the number of audit clients in each firm office for each firm-year in the sample. Industry fixed effects are included to control for industry variation. All other variable definitions are consistent with Equation 2.

Table 8 reports the ordinary least regression of Equation 10. This test uses observations in the post-ISA 700 period only because auditors have much less flexibility in audit reporting in the pre-ISA 700 period. Column 1 shows that readability improves when a Big $\mathrm{N}$ firm issues the audit report. The coefficient is negative and significant $(\mathrm{p}<0.05)$. This finding is consistent with untabulated univariate tests comparing readability statistics by firm. ${ }^{15}$ Column 2 shows the coefficient on $O F F I C E \_S I Z E(\mathrm{p}<$ 0.05) is negative and significant providing evidence that larger offices generate reports that are more readable.

\footnotetext{
${ }^{15}$ The Big N firms had the largest average FOG change with a decrease of 4.96 points compared to the Non-Big N firms that had an average FOG change of 1.67 points.
} 
Columns 3 and 4 include the results when evaluating industry expertise and the association with readability. Consistent with the results in Columns 1 and 2, the coefficient on EXP_NUMCLT and EXP_DOMINANCE are both negative and significant at the $1 \%$ level. Based on the results in Column 4, the effect is slightly stronger for the dominant industry leader. Columns 5 and 6 show the results of the full model including the Big N, office size, and industry expertise variables. When measuring industry expertise by the number of clients, Column 5 shows that $B I G N$ and $E X P_{-} N U M C L T$ are significant at the $10 \%$ and $5 \%$ level, respectively. In Column 6, when industry expertise is measured by industry dominance, the coefficient on EXP_DOMINANCE is negative and significant $(\mathrm{p}<0.01)$ with $B I G N$ maintaining marginal significance $(\mathrm{p}<0.10)$. Taken together, the results from Columns 5 and 6 show that industry expertise is more strongly associated with improved readability. The results from Table 8 show that higher readability is associated with higher audit quality characteristics providing support that a more readable, hence a more usable report, contributes to audit quality. ${ }^{16}$

\section{ISA 700 Audit Report Readability and Audit Firms}

Recent analyst and regulatory reports on the implementation of ISA 700 have noted variation in the "quality of risk discussion" (Citi Research 2014a; Citi Research 2014b; FRC 2015; FRC 2016) among the auditors of FTSE 100 companies. ISA 700

\footnotetext{
${ }^{16}$ For brevity, I do not report the results of auditor characteristics and report tone. The inferences are similar. In sum, I find that high quality auditor characteristics are associated with changes in tone in the ISA 700 period. BIGN firms are associated with more negative words $(\mathrm{p}<0.10)$ in the ISA 700 audit reports, but industry experts $($ EXP_CLIENT or EXP_DOMINANCE) use fewer negative words $(\mathrm{p}<0.01)$. BIGN firms and industry experts are not associated with positive word use in the ISA 700 audit reports. Similar to the negative word finding, industry experts use fewer uncertain words $(\mathrm{p}<0.01)$.
} 
reports generated by Ernst \& Young (EY) are characterized as having less risk disclosures than the other Big 4 international accounting firms (Citi Research 2014b).

To evaluate whether there is also variation in the readability of audit reports, I perform a firm analysis on readability in the year of implementation. I modify Equation 2 to include an indicator variable, $E Y$, that equals one if the auditor is $E Y$ and zero otherwise resulting in Equation 11. I add an interaction variable $N E W O P^{*} E Y$ to Equation 11 resulting in Equation 12.

$$
\begin{aligned}
& \text { FOG } \quad=\beta_{0}+\beta_{1} E Y_{i t}+\beta_{2} S I Z E_{i t}+\beta_{3} M B_{i t} \\
& +\beta_{4} A G E_{i t}+\beta_{5} S I_{i t}+\beta_{6} E A R N_{-} V O L_{i t}+\beta_{7} N B S E G_{i t} \\
& +\beta_{8} \text { ACQUISITION }{ }_{i t}+\beta_{9} \text { SEO }_{i t} \\
& +\beta_{10} \text { COMBINED_OP } i t+\text { Industry Effects }+\varepsilon \\
& \text { FOG } \quad=\beta_{0}+\beta_{1} \text { NEWOPINION }_{i t}+\beta_{2} E Y_{i t}+\beta_{3} \text { NEWOP }^{*} E Y_{i t} \\
& +\beta_{4} S_{I Z E_{i t}}+\beta_{5} M B_{i t}+\beta_{6} A G E_{i t}+\beta_{7} S_{i t}+\beta_{8} E A R N_{-} V O L_{i t} \\
& +\beta_{9} N_{B S E G}+\beta_{10} \text { ACQUISITION }_{i t}+\beta_{11} \text { SEO }_{i t}+ \\
& +\beta_{12} \text { COMBINED_OP } i t+\text { Industry Effects }+\varepsilon
\end{aligned}
$$

Table 9 reports the results of the ordinary least squares regression of Equations 11 and 12. Column 1 reports the coefficient on $E Y$ of 1.062 is positive and significant indicating that an average person would need one additional year of formal education to read and comprehend audit reports generated by EY. In Column 2, the interaction coefficient on $N E W O P^{*} E Y$ of 3.86 is significant at the $1 \%$ level indicating that approximately four more levels of education are necessary to read the audit reports generated by EY in the post-ISA 700 period compared to other firms. This shows that 
opportunity remains for audit firms to provide more readable and informative audit reports in future implementation periods. ${ }^{17}$

\section{Alternative Tone Measures Analysis}

With the advent of the expanded audit report in the UK, the words describing the audit reflect the linguistic choice of auditors. Prior accounting literature has evaluated the linguistic choice of managers when analyzing the tone of Form 10-Ks, conference calls, and press releases (Li 2010; Matsumoto et al. 2011; Henry 2008; Henry 2006). Henry and Leone (2016) evaluate tone measures used in the capital markets literature to provide evidence on the differences in general and domain-specific word lists when analyzing financial texts. In addition, the authors compare the dictionary approach to more complicated content analyses such as natural language processing and inverse document frequency (idf) weighting (Henry and Leone 2016). I extend their evaluation of tone measures into the audit report setting using the introduction of the ISA 700 report to: 1) further examine audit report tone; 2) assess differences in word dictionaries used in content analysis; and 3) determine if tone measures created in the management disclosure setting are also relevant in the new auditor disclosure setting.

In the test of Hypothesis 1a, I utilize the Loughran and McDonald (LM) (2011) negative, positive, and uncertain word dictionaries. To evaluate whether alternative tone measures also show increased word choice and negative tone as shown in the Table 4

\footnotetext{
${ }^{17}$ In untabulated analyses, I also evaluate each of the remaining Big $\mathrm{N}$ firms using the same model construction as Equations 11 and 12. The interaction coefficient on $P W C * N E W O P$ of -2.67 is significant at the $1 \%$ level. The interaction coefficient on $K P M G^{*} N E W O P$ was also negative (-0.34) but not significant. $D T * N E W O P$ was positive (0.22) but not significant. These results show the variation in ISA 700 implementation across the international firms and indicate areas for additional improvement.
} 
results, I construct three additional tone measures following the variable construction in Henry and Leone (2016). ${ }^{18}$

TONE_LM = (POSITIVE-NEGATIVE) $/($ POSITIVE + NEGATIVE $)$ Where POSITIVE and NEGATIVE refer to the word count frequency based on the positive and negative words in the Loughran and McDonald word lists, respectively.

TONE_FD Henry = (POSITIVE-NEGATIVE $)($ POSITIVE + NEGATIVE $)$ Where POSITIVE and NEGATIVE refer to the word count frequency based on the positive and negative words in the FD Henry word lists, respectively.

TONE_LIWC $\quad=($ POSITIVE-NEGATIVE $) /(P O S I T I V E+N E G A T I V E)$ Where POSITIVE and NEGATIVE refer to the word count frequency based on the positive emotion and negative emotion words in the LIWC word list, respectively.

The LM and FD Henry word lists are domain-specific based on financial texts such as Form 10-Ks and earnings press releases. The LIWC word list is a general list created to evaluate a wide variety of written and spoken texts. Following the tone interpretation in Henry and Leone (2016), an audit report with a maximum positive tone results in a tone score of one (1). An audit report with a maximum negative tone results in a tone score of negative one (-1). An audit report with a neutral tone results in a tone score of zero (0).

\footnotetext{
${ }^{18}$ As noted in Section III, the LM word lists include 2,355 negative words and 354 positive words. The FD Henry word lists are derived from Henry $(2006,2008)$ include 93 negative words and 117 positive words (Henry 2006; Henry 2008). The LIWC word lists, created by Pennebaker, Chung, Ireland, Gonzales, and Booth (2007) as a part of the LIWC text analysis software, provide an efficient method of analyzing the structural, emotional, and cognitive components of written language (Pennebaker et al. 2007). The LIWC word lists include 499 negative words and 408 positive words.
} 
I modify the dependent variable, TONE, in Equation 3 to represent the alternative tone measures, TONE_LM, TONE_FD Henry, and TONE_LIWC. I expect that, consistent with the findings in Table 4, the post-ISA 700 audit report will have a more negative tone reflected in a negative coefficient on NEWOPINION. Additionally, I expect a higher usage of domain-specific words in the post-ISA 700 reports.

Table 10 reports the univariate and multivariate results evaluating the alternative tone measures. Panel A shows the univariate analysis of the tone measures and the audit report word frequency for each word list (LM, FD Henry, or LIWC). All tone measures show a statistically significant decrease in tone when comparing the post-ISA 700 reports to the pre-ISA 700 reports. The tone measures based on domain-specific word lists (LM and FD Henry) are both negative in the post-ISA 700 period. However, the tone measure based on the general word list (LIWC) had a positive tone in both periods, but was less positive in the post-ISA 700 period. When examining the coverage of audit report words by the each of the three word lists, an interesting trend emerges. The domain-specific word lists, LM and FD Henry, only capture $3.8 \%$ and $1.5 \%$ of the postISA 700 audit report words, respectively. On the other hand, the LIWC word lists captures $79 \%$ of the audit report words in both the pre- and post-ISA 700 periods. This difference in word capture between domain-specific and general word lists provides some evidence that audit reports may include more common language than disclosures generated by management. This evidence is consistent with both anecdotal and regulatory views on the expanded audit report that indicate a less complicated discussion of audit matters in the report. 
Panel B of Table 10 reports the ordinary least squares regression of Equations 11-13. Column 1 reports a negative and significant $(\mathrm{p}<0.01)$ coefficient on NEWOPINION when TONE_LM is the dependent variable. Columns 2 and 3 report similar results when TONE_FD Henry and TONE_LIWC are the dependent variables. These results further support the univariate analysis and the Table 4 results that the postISA 700 reports had a negative tone indicating the reports captured the underlying risks of the audit. Although the test results are consistent, the explanatory power of each model varies. The $\mathrm{R}^{2}$ for Column 1 is $37.25 \%$ compared to $69.92 \%$ in Column 2 and $81.12 \%$ in Column 3. These differences in explanatory power shows the importance of word list selection when evaluating different types of financial texts. Appendix C summarizes the most frequent domain-specific words included in the pre- and post-ISA 700 audit reports.

\section{ISA 700 Implementation and Market Response}

Contemporaneous studies (Gutierrez et al. 2016; Reid et al. 2015; Lennox et al. 2015) evaluate the market reaction to the introduction of ISA 700 reporting. Although my study focuses on the auditor's response to ISA 700, I also examine market response using abnormal trading volume $(A V O L)$ and abnormal returns $(A B R E T) .{ }^{19}$ In untabulated analysis, I find a negative and insignificant $(-0.03, \mathrm{p}=0.54)$ association between NEWOPINION and AVOL. I also find a positive but insignificant association

\footnotetext{
${ }^{19}$ AVOL is calculated as the mean daily trading volume during the event period $(-1,0,1)$ minus the mean daily trading volume during the non-filing period $(-61,-21)$ deflated by the standard deviation of daily trading volume during the non-filing period $(-61,-21)$. The estimation period is based on the earnings announcement date to avoid capturing trading volume related to the release of earnings. ABRET is calculated as company returns minus London Stock Exchange value weighted returns for the event period $(-1,0,1)$.
} 
(0.01, p=0.31) between $F O G$ and $A V O L$. Further, in assessing abnormal returns, I find a positive and insignificant association between NEWOPINION and ABRET $(0.00$, $\mathrm{p}=0.63$ ). Consistent with the $A V O L$ tests, I finds a negative and insignificant association between $F O G$ and $A B R E T(-0.00, \mathrm{p}=0.27)$. Taken together, this provides evidence that the market did not have an observable response to the introduction of the expanded audit report. 


\section{SUMMARY AND CONCLUSION}

The introduction of ISA 700 presented a significant shift in auditor disclosure included in the audit report. The FRC designed the additional disclosures on risks of material misstatement and audit scoping decisions to make the standard audit report more informative to the audit report user. I examine whether introduction of ISA 700 changes the communication value of the audit report. Using readability and tone to measure communication value allows for a direct evaluation of the effectiveness of the expanded audit report. In addition, I address the financial statement users' response to the expanded audit report by evaluating analyst following and analyst forecast dispersion. Finally, I investigate the association of the expanded audit report with audit firm characteristics associated with high quality audits.

I find that audit reports in the post-ISA 700 period are more readable indicating improved communication value. I show that ISA 700 adoption resulted in more negative and uncertain audit report tone. This indicates that auditors capture the underlying risks of their clients by utilizing negative and uncertain words in the expanded audit report. The audit report tone results also provide indirect evidence that the auditor disclosures were not boilerplate but varied in language choice. In evaluating the financial statement users' response, I find that both analyst following and analyst forecast dispersion decreased lending support that the expanded audit report effected financial statement user behaviors.

My study contributes to the audit literature in three ways. First, my paper is the first to provide a content analysis of the expanded audit report to gain insight into how 
and what auditors communicate using the expanded audit report and adds significantly to readability and tone literatures. Second, my findings are useful to standard-setters and regulators. ISA 700 reports are easier to read and provide more information to assist investors and information intermediaries in making informed investment decisions. In addition, the ISA 700 reports are not boilerplate in nature and adequately capture the underlying client-specific audit risks through negative and uncertain word usage. I also contribute to the literature by showing that high-quality auditor characteristics are associated with producing more readable audit reports. Finally, I provide initial evidence in word choice differences in auditor disclosure compared to management disclosure. This study should be of interest to standard-setters, regulators, and academics as the study provides a content-based approach to evaluating the implementation of expanded auditor disclosure that can inform future standard setting. 


\section{REFERENCES}

American Institute of Accountants (AIA). 1948. Statements on Auditing Procedure No. 24, Revision in Short-Form Accountant's Report or Certificate. New York, NY.

American Institute of Certified Public Accountants (AICPA). 1988. Reports on Audited Financial Statements. New York, NY.

Antweiler, W., and M. Z. Frank. 2004. Is all that talk just noise? The information content of internet stock message boards. Journal of Finance 59 (3): 1259-1294.

Auditing Practices Committee (APC). 1980. The Audit Report. London, UK.

Asare, S. K., and A. M. Wright. 2012. Investors', auditors', and lenders' understanding of the message conveyed by the standard audit report on the financial statements. Accounting Horizons 26 (2): 193-217.

Balsam, S., J. Krishnan, and J. S. Yang. 2003. Auditor industry specialization and earnings quality. AUDITING: A Journal of Practice \& Theory 22 (2): 71-97.

Barnett, A., and K. Loeffler. 1979. Readability of accounting and auditing messages. Journal of Business Communication: 49-59.

Barth, M. E., R. Kasznik, and M. F. McNichols. 2001. Analyst coverage and intangible assets. Journal of Accounting Research 39 (1): 1-34.

Beattie, V. 2014. Accounting narratives and the narrative turn in accounting research: Issues, theory, methodology, methods and a research framework. The British Accounting Review 46 (2): 111-134.

Bhushan, R. 1989. Firm characteristics and analyst following. Journal of Accounting and Economics 11 (2-3): 255-274.

Bloomfield, R. J. 2002. The "incomplete revelation hypothesis" and financial reporting. Accounting Horizons 16 (3): 233-243.

Bonsall, S. B., A. J. Leone, and B. P. Miller. 2015. A plain english measure of financial reporting readability. Working Paper, The Ohio State University, University of Miami, and Indiana University.

Brennan, M. J., and A. Subrahmanyam. 1995. Investment analysis and price formation in securities markets. Journal of Financial Economics 38 (3): 361-381.

Brown, L. D., A. C. Call, M. B. Clement, and N. Y. Sharp. 2014. Skin in the game: The inputs and incentives that shape buy- side analysts' stock recommendations. 
Working Paper, Temple University, Arizona State University, University of Texas at Austin, and Texas A\&M University.

- 2015. Inside the "black box" of sell-side financial analysts. Journal of Accounting Research 53 (1): 1-47.

CFA Institute. 2010. Independent Auditor's Report Survey Results. Charlottesville, VA.

Choi, J.-H., C. (Francis) Kim, J.-B. Kim, and Y. Zang. 2010. Audit office size, audit quality, and audit pricing. AUDITING: A Journal of Practice \& Theory 29 (1): 7397.

Christensen, B. E., S. M. Glover, and C. J. Wolfe. 2014. Do critical audit matter paragraphs in the audit report change nonprofessional investors' decision to invest? AUDITING: A Journal of Practice \& Theory 33 (4): 71-93.

Church, B. K., S. M. Davis, and S. A. Mccracken. 2008. The auditor's reporting model : A literature overview and research synthesis. Accounting Horizons 22 (1): 69-90.

Citi Research. 2014a. New UK Auditor's Reports. A Review of New Information.

- 2014b. New UK Auditor's Reports Update: Findings from the FTSE $100 \mathrm{New}$ Auditor's Reports.

Clatworthy, M., and M. J. Jones. 2001. The effect of thematic structure on the variability of annual report readability. Accounting, Auditing \& Accountability Journal 14 (3): 311-326.

Coram, P. J., T. J. Mock, J. L. Turner, and G. L. Gray. 2011. The communicative value of the auditor's report. Australian Accounting Review 21 (3): 235-252.

Courtis, J. K. 1995. Readability of annual reports : Western versus asian evidence. Accounting, Auditing \& Accountability Journal 8 (2): 4-17.

- 1998. Annual report readability variability: Tests of the obfuscation hypothesis. Accounting, Auditing \& Accountability Journal 11 (4): 459-472.

DeAngelo, L. E. 1981. Auditor independence, "low balling", and disclosure regulation. Journal of Accounting and Economics 3: 113-127.

Defond, M., D. H. Erkens, and J. Zhang. 2014. Do client characteristics really drive the Big $\mathrm{N}$ audit quality effect? Working Paper, University of Southern California and University of Texas at Dallas.

DeFond, M., and J. Zhang. 2014. A review of archival auditing research. Journal of Accounting and Economics 58 (2-3): 275-326. 
Doogar, R., S. P. Rowe, and P. Sivadasan. 2015. Asleep at the wheel (again)? Bank audits during the lead-up to the financial crisis. Contemporary Accounting Research 32 (1): 358-391.

Dopuch, N., and D. Simunic. 1982. Competition in auditing: An assessment. In Fourth Symposium on Auditing Research. Urbana, IL: University of Illinois.

Engelberg, J. E., A. V. Reed, and M. C. Ringgenberg. 2012. How are shorts informed? Journal of Financial Economics 105 (2): 260-278.

Ferguson, A., J. R. Francis, and D. J. Stokes. 2003. The effects of firm-wide and officelevel industry expertise on audit pricing. The Accounting Review 78 (2): 429-448.

Francis, J. R., P. N. Michas, and M. D. Yu. 2013. Office size of Big 4 auditors and client restatements. Contemporary Accounting Research 30 (4): 1626-1661.

Francis, J. R., K. Reichelt, and D. Wang. 2005. The pricing of national and city-specific reputations for industry expertise in the US audit market. The Accounting Review 80 (1): 113-136.

Francis, J. R., and M. D. Yu. 2009. Big 4 office size and audit quality. The Accounting Review 84 (5): 1521-1552.

De Franco, G., O.-K. Hope, D. Vyas, and Y. Zhou. 2015. Analyst report readability. Contemporary Accounting Research 32 (1): 76-104.

Frankel, R., S. P. Kothari, and J. Weber. 2006. Determinants of the informativeness of analyst research. Journal of Accounting and Economics 41 (1-2): 29-54.

Financial Reporting Council (FRC). 1993. Auditors 'Reports on Financial Statements. London, UK.

—. 2006. Discussion Paper - Promoting Audit Quality. London, UK.

- 2007. Discussion Paper - The Auditor's Report: A Time for Change? London, UK.

- 2013a. International Standard on Auditing ( UK and Ireland ) 700 The independent auditor 's report on financial statements. London, UK.

_. 2013b. FRC issues revised auditing standard: making auditors' work more transparent to investors. London, UK.

- 2013c. Consultation Paper - Revision to ISA ( UK and Ireland) 700 Requiring the auditor 's report to address risks of material misstatement, materiality and a summary of audit scope. London, UK. 
- 2015. Extended Auditor's Reports - A review of experience in the first year. London, UK.

—. 2016. Extended Auditor's Reports: A Further Review of Experience. London, UK.

Geiger, M. A. 1994. The New Auditor's Report. Journal of Accountancy (November): $59-64$.

Gray, G. L., J. L. Turner, P. J. Coram, and T. J. Mock. 2011. Perceptions and misperceptions regarding the unqualified auditor's report by financial statement preparers, users, and auditors. Accounting Horizons 25 (4): 659-684.

Gunning, R. 1952. The Technique of Clear Writing. New York, NY: McGraw-Hill.

Gurun, U. G., and A. W. Butler. 2012. Don't believe the hype: Local media slant, local advertising, and firm value. Journal of Finance 67 (2): 561-598.

Gutierrez, E., M. Minutti-Meza, K. W. Tatum, and M. Vulcheva. 2016. Consequences of changing the auditor's report : Early evidence from the UK. Working Paper, Universidad de Chile, University of Miami, and Florida International University.

Healy, P. M., and K. G. Palepu. 2001. Information asymmetry, corporate disclosure, and the capital markets: A review of the empirical disclosure literature. Journal of Accounting and Economics 31 (1-3): 405-440.

Henry, E. 2006. Market reaction to verbal components of earnings press releases: Event study using a predictive algorithm. Journal of Emerging Technologies in Accounting 3: 1-19.

-2008. Are investors influenced by how earnings press releases are written? Journal of Business Communication 45 (4): 363-407.

Henry, E., and A. J. Leone. 2016. Measuring qualitative information in capital markets research. The Accounting Review 91 (1): 153-178.

Hermanson, R., P. Duncan, and J. V. Carcello. 1991. Does the new audit report improve communication with investors? Ohio CPA Journal (May/June): 32-37.

Hronsky, J. J. F. 1998. Signs, codes and communication: The semiotics of audit reports. Working Paper, University of Melbourne.

International Auditing and Assurance Standards Board (IAASB). 2011. Enhancing the Value of Auditor Reporting : Exploring Options for Change. New York, NY. 2015. The New Auditor's Report: Greater Transparency into the Financial 
Statement Audit. New York, NY.

Institute of Chartered Accountants in England and Wales (ICAEW). 2007. Audit Quality Fundamentals - Auditor Reporting. London, UK.

International Organization of Securities Commissions (IOSCO). 2009. Auditor Communications Consultation Report. Madrid, Spain.

Jones, M. J., and P. A. Shoemaker. 1994. Accounting narratives: A review of empirical studies of content and readability. Journal of Accounting Literature 13: 142-184.

Kachelmeier, S. J., J. J. Schmidt, and K. Valentine. 2014. The effect of disclosing critical audit matters in the auditor's report on perceived auditor responsibility for misstatements. Working Paper, University of Texas at Austin.

Lehavy, R., F. Li, and K. Merkley. 2011. The effect of annual report readability on analyst following and the properties of their earnings forecasts. The Accounting Review 86 (3): 1087-1115.

Lennox, C. S., J. J. Schmidt, and A. M. Thompson. 2015. Is the expanded model of audit reporting informative to investors? Evidence from the UK. Working Paper, University of Southern California, University of Texas at Austin, and University of Illinois at Urbana-Champaign.

Lewis, N. R., L. D. Parker, G. D. Pound, and P. Sutcliffe. 1986. Accounting report readability: The use of readability techniques. Accounting and Business Research 16 (63): 199-213.

Li, F. 2008. Annual report readability, current earnings, and earnings persistence. Journal of Accounting and Economics 45 (2-3): 221-247.

. 2010. Textual analysis of corporate disclosures: A survey of the literature. Journal of Accounting Literature 29: 143-165.

Loughran, T., and B. McDonald. 2011. When is a liability not a liability? Textual analysis, dictionaries, and 10-Ks. Journal of Finance 66 (1): 35-65.

-2014. Measuring readability in financial disclosures. Journal of Finance 69 (4): $1643-1671$.

Manson, S., and M. Zaman. 2001. Auditor communication in an evolving environment: Going beyond SAS 600 auditors' reports on financial statements. The British Accounting Review 33 (2): 113-136.

Marston, C. 1997. Firm characteristics and analyst following in the UK. The British Accounting Review 29 (4): 335-347. 
Matsumoto, D., M. Pronk, and E. Roelofsen. 2011. What makes conference calls useful? The information content of managers' presentations and analysts' discussion sessions. The Accounting Review 86 (4): 1383-1414.

Miller, J. R., S. A. Reed, and R. H. Strawser. 1990. The new auditor's report : Will it close the expectations gap in communications? The CPA Journal (May): 68-72.

. 1993. Bank loan officers' perceptions of the new audit report. Accounting Horizons 7 (1): 39-52.

Mock, T. J., J. Bédard, P. J. Coram, S. M. Davis, R. Espahbodi, and R. C. Warne. 2013. The audit reporting model: Current research synthesis and implications. AUDITING: A Journal of Practice \& Theory 32 (Supplement 1): 323-351.

Mock, T. J., J. L. Turner, G. L. Gray, and P. J. Coram. 2009. The Unqualified Auditor's Report: A Study of User Perceptions, Effects on User Decisions and Decision Processes, and Directions for Further Research. A Report to the Auditing Standards Board and the International Auditing and Assurance Standards Board (June). New York, NY.

O’Brien, P. C., and R. Bhushan. 1990. Analyst following and institutional ownership. Journal of Accounting Research 28 (Supplement 1990): 55-76.

Osborne, A. 2011. Were Big Four Auditors Just Guilty of Failing to see Wood for the Trees? The Telegraph (UK).

Public Company Accounting Oversight Board (PCAOB). 2007. Auditing Standard No. 5 - An Audit of Internal Control over Financial Reporting That Is Integrated with an Audit of Financial Statements. Washington, DC.

- 2010. Standing Advisory Group Meeting - ACAP Committee's Recommendation Relating to the Auditor's Reporting Model. Washington, DC.

- 2013. Proposed Auditing Standards - The Auditor's Report on an Audit of Financial Statements when the Auditor Expresses and Unqualified Opinion. Washington, DC.

—. 2014. PCAOB April 2, 2014 Public Meeting on the Auditor's Reporting Model.

- 2016. Proposed Auditing Standard - The Auditor's Report on an Audit of Financial Statements When the Auditor Expresses an Unqualified Opinion. Washington, DC.

Pearce, A. 2014. Mixed Verdict on New-Look Audit Reports. Finanical News, November. 
Pennebaker, J. W., C. K. Chung, M. Ireland, A. Gonzales, and R. J. Booth. 2007. The development and psychometric properties of LIWC2007. Austin, TX.

Pound, G. D. 1981. A note on audit report readability. Accounting \& Finance 21: 45-55.

Reichelt, K. J., and D. Wang. 2010. National and office-specific measures of auditor industry expertise and effects on audit quality. Journal of Accounting Research 48 (3): 647-686.

Reid, L. C., J. V. Carcello, C. Li, and T. L. Neal. 2015. Are auditor and audit committee report changes useful to investors? Evidence from the United Kingdom. Working Paper, University of Pittsburgh and University of Tennessee.

Rogers, J. L., A. Van Buskirk, and S. L. C. Zechman. 2011. Disclosure tone and shareholder litigation. The Accounting Review 86 (6): 2155-2183.

Shannon, C. E., and W. Weaver. 1949. The Mathematical Theory of Communication. Urbana, IL: University of Illinois Press.

Sikka, P. 2009. Financial crisis and the silence of the auditors. Accounting, Organizations and Society 34 (6-7): 868-873.

Smith, J. E., and N. P. Smith. 1971. Readability: A measure of the performance of the communication function of financial reporting. The Accounting Review 46 (3): 552561 .

Soper, F. J., and R. Dolphin. 1964. Readability and corporate annual reports. The Accounting Review 39 (2): 358-362.

Tetlock, P. C. 2007. Giving content to investor sentiment: The role of media in the stock market. Journal of Finance 62 (3): 1139-1168.

Tetlock, P. C., M. Saar-Tsechansky, and S. MacSkassy. 2008. More than words: Quantifying language to measure firms' fundamentals. Journal of Finance 63 (3): 1437-1467.

Turner, J. L., T. J. Mock, P. J. Coram, and G. L. Gray. 2010. Improving transparency and relevance of auditor communications with financial statement users. Current Issues in Auditing 4 (1): A1-A8. 


\section{APPENDIX A}

\section{VARIABLE DEFINITIONS}

\begin{tabular}{|c|c|}
\hline \multicolumn{2}{|c|}{ Dependent Variables - Main Analyses } \\
\hline$F O G$ & Calculated as words per sentence + percent of complex words) $\mathrm{x} 0.4$. \\
\hline NEGATIVE & $\begin{array}{l}\text { Represents the word count frequency in the audit report based on the } \\
\text { Loughran and McDonald Negative Word List. }\end{array}$ \\
\hline POSITIVE & $\begin{array}{l}\text { Represents the word count frequency in the audit report based on the } \\
\text { Loughran and McDonald Positive Word List. }\end{array}$ \\
\hline UNCERTAIN & $\begin{array}{l}\text { Represents the word count frequency in the audit report based on the } \\
\text { Loughran and McDonald Uncertain Word List. }\end{array}$ \\
\hline COMBINED_TONE & Calculated as the sum of NEGATIVE, POSITIVE, and UNCERTAIN. \\
\hline FOLLOWING & $\begin{array}{l}\text { Calculated as the number of analysts included in the first consensus forecast } \\
\text { estimate after audit report issuance. }\end{array}$ \\
\hline DISPERSION & $\begin{array}{l}\text { Calculated as the standard deviation of the individual analyst forecasts in } \\
\text { the first analyst consensus forecast (annual) after audit report issuance, } \\
\text { scaled by the share price } 90 \text { days prior to the consensus forecast date. }\end{array}$ \\
\hline \multicolumn{2}{|c|}{ Dependent Variables - Supplemental Analyses } \\
\hline TONE_LM & $\begin{array}{l}\text { Calculated as (POSITIVE-NEGATIVE)/(POSITIVE + NEGATIVE), where } \\
\text { POSITIVE and NEGATIVE refer to the word count frequency based on the } \\
\text { positive and negative words in the Loughran and McDonald word lists, } \\
\text { respectively. }\end{array}$ \\
\hline TONE_FD Henry & $\begin{array}{l}\text { Calculated as (POSITIVE-NEGATIVE)/(POSITIVE + NEGATIVE), where } \\
\text { POSITIVE and NEGATIVE refer to the word count frequency based on the } \\
\text { positive and negative words in the Loughran and McDonald word lists, } \\
\text { respectively. }\end{array}$ \\
\hline TONE_LIWC & $\begin{array}{l}\text { Calculated as (POSITIVE-NEGATIVE)/(POSITIVE + NEGATIVE), where } \\
\text { POSITIVE and NEGATIVE refer to the word count frequency based on the } \\
\text { positive and negative words in the LIWC word lists, respectively. }\end{array}$ \\
\hline \multicolumn{2}{|l|}{ Test Variables } \\
\hline NEWOPINION & $\begin{array}{l}\text { Is an indicator variable equal to one if the audit opinion is issued in the first } \\
\text { year of ISA } 700 \text { implementation and zero otherwise (the year immediately } \\
\text { prior to ISA } 700 \text { implementation). }\end{array}$ \\
\hline$F O G$ & Calculated as words per sentence + percent of complex words) x 0.4 . \\
\hline$B I G N$ & $\begin{array}{l}\text { Is an indicator variable equal to one if the auditor is one of the big four } \\
\text { international accounting firms in year } t \text { and zero otherwise. }\end{array}$ \\
\hline$E X P \_N U M C L T$ & $\begin{array}{l}\text { Is equal to one, if the company is audited by an audit firm with the most } \\
\text { clients in that industry when compared to all other audit firms in the sample, } \\
\text { in year } t \text { and zero otherwise. }\end{array}$ \\
\hline EXP_DOMINANCE & $\begin{array}{l}\text { Is equal to one if the company is audited by an audit firm that has } 10 \% \text { more } \\
\text { audit clients in an industry than the firm's nearest competitor in year } t \text { and } \\
\text { zero otherwise. }\end{array}$ \\
\hline OFFICE_SIZE & $\begin{array}{l}\text { Equals the number of audit clients in each firm office for each firm-year in } \\
\text { the sample. }\end{array}$ \\
\hline$E Y$ & $\begin{array}{l}\text { Is equal to one, if the company is audited by EY in year } t \text { and zero } \\
\text { otherwise. }\end{array}$ \\
\hline \multicolumn{2}{|l|}{ Control Variables } \\
\hline ACQUISITION & $\begin{array}{l}\text { Is an indicator variable equal to one if the company's acquisition expense is } \\
\text { greater than zero in year } t \text { and zero otherwise. }\end{array}$ \\
\hline
\end{tabular}




\begin{tabular}{|c|c|}
\hline$A G E$ & $\begin{array}{l}\text { Represents the number of years since the company's IPO at the end of year } \\
t \text {. }\end{array}$ \\
\hline$B I G N$ & $\begin{array}{l}\text { Is an indicator variable equal to one if the auditor is one of the big four } \\
\text { international accounting firms in year } t \text { and zero otherwise. }\end{array}$ \\
\hline$B U S Y$ & $\begin{array}{l}\text { Is an indicator variable equal to one if the company's fiscal year end is from } \\
\text { December to March and zero otherwise. }\end{array}$ \\
\hline COMBINED_OP & $\begin{array}{l}\text { Is an indicator variable equal to one if the audit report includes both the } \\
\text { group audit report and the parent company audit report in year } t \text { and zero } \\
\text { otherwise. }\end{array}$ \\
\hline CROSS_LIST & $\begin{array}{l}\text { Is an indicator variable equal to one if the company is listed on a US stock } \\
\text { exchange and zero otherwise. }\end{array}$ \\
\hline$E A R N \_V O L$ & $\begin{array}{l}\text { Represents the standard deviation of earnings over the prior five year period } \\
\text { at the end of year } t \text {. }\end{array}$ \\
\hline Industry Fixed Effects & Fama and French 12 Industry Classification \\
\hline INST & $\begin{array}{l}\text { Decile ranking of the number of the company's shares held by institutional } \\
\text { investors divided by the number of the company's shares outstanding at the } \\
\text { end of the fiscal year. }\end{array}$ \\
\hline LOGSIZE & $\begin{array}{l}\text { Represents the logarithmic transformation of market value at the end of year } \\
\text { prior to the issuance of the audited financial report. }\end{array}$ \\
\hline $\log F I L E S I Z E$ & Represents the logarithmic transformation of the file size of the audit report. \\
\hline LOSS & $\begin{array}{l}\text { Is an indicator variable equal to one if the firms has net income of less than } \\
\text { zero and zero otherwise. }\end{array}$ \\
\hline$M B$ & $\begin{array}{l}\text { Represents the market value at the end of year } \mathrm{t} \text { divided by the book value at } \\
\text { the end of year } t \text {. }\end{array}$ \\
\hline NBSEG & $\begin{array}{l}\text { Represents the logarithmic transformation of the number of business } \\
\text { segments included in the Bureau van Dijk dataset. }\end{array}$ \\
\hline$R D$ & $\begin{array}{l}\text { Represents the ratio of research and development expenses to total operating } \\
\text { expenses for the fiscal year. }\end{array}$ \\
\hline SEO & $\begin{array}{l}\text { Is an indicator variable equal to one if the company is listed in the Thomson } \\
\text { One Equity Issuance Database as issuing an equity offering in year } t \text { and } \\
\text { zero otherwise. }\end{array}$ \\
\hline$S I$ & $\begin{array}{l}\text { Represent the amount of special items scaled by total assets at the end of } \\
\text { year } t \text {. }\end{array}$ \\
\hline SIZE & Represents the logarithmic transformation of total assets at the end of year $t$. \\
\hline
\end{tabular}




\section{APPENDIX B}

\section{FIGURES AND TABLES}

\section{Figure 1 \\ Audit Report Communication Model}
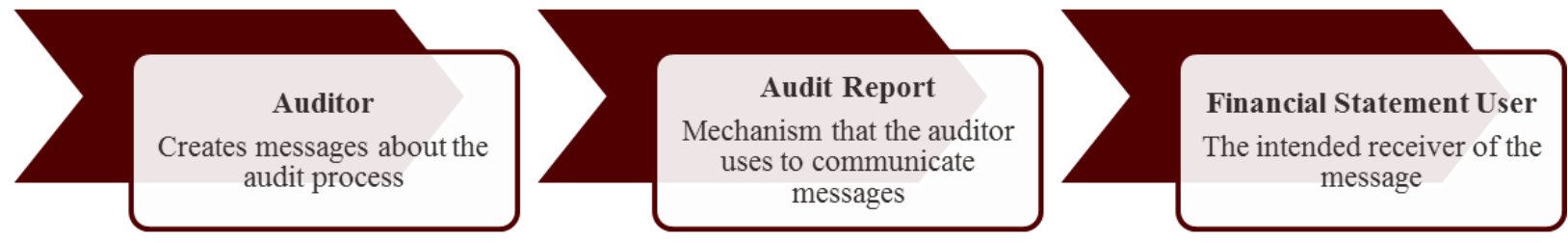
TABLE 1

Sample Size Calculation

\section{Sample Criteria}

Companies in Compustat Global listed on the London Stock Exchange (LSE) or Irish Stock Exchange with fiscal year ends from 2012 - 2014

Less: Company fiscal year ends prior to the year immediately before ISA 700 implementation

Less: Non LSE Premium Companies

Less: Banks and Financial Institutions

Less: Observations without readability data

Less: Companies without available stock data

\section{Full Sample}

\begin{tabular}{cc} 
Companies & $\begin{array}{c}\text { Observations } \\
\boldsymbol{t} \text { and } \boldsymbol{t} \mathbf{1}\end{array}$ \\
\hline 1,680 & 3,360 \\
$(101)$ & $(202)$ \\
$(871)$ & $(1,742)$ \\
$(250)$ & $(500)$ \\
\hline 458 & 916 \\
$(30)$ & $(60)$ \\
$(78)$ & $(156)$ \\
\hline 350 & 700
\end{tabular}


TABLE 2

Descriptive Statistics

\begin{tabular}{|c|c|c|c|c|c|c|}
\hline & $\mathrm{N}$ & Mean & Median & $\begin{array}{c}\text { Standard } \\
\text { Deviation }\end{array}$ & $\begin{array}{c}25^{\text {th }} \\
\text { Percentile }\end{array}$ & $\begin{array}{c}75^{\text {th }} \\
\text { Percentile }\end{array}$ \\
\hline NEWOPINION & 700 & 0.50 & 0.50 & 0.50 & 0.00 & 1.00 \\
\hline$F O G$ & 700 & 27.35 & 27.24 & 3.16 & 24.30 & 29.90 \\
\hline FOLLOWING & 620 & 10.70 & 9.00 & 6.79 & 4.00 & 16.00 \\
\hline DISPERSION & 566 & 0.30 & 0.23 & 0.25 & 0.07 & 0.47 \\
\hline LOGFEES & 700 & 13.00 & 12.90 & 1.05 & 12.21 & 13.71 \\
\hline$R A W \_F E E S$ (millions) & 700 & 0.77 & 0.40 & 0.85 & 0.20 & 0.90 \\
\hline$B I G \bar{N}$ & 700 & 0.93 & 1.00 & 0.26 & 1.00 & 1.00 \\
\hline$O P \_P A G E S$ & 700 & 2.29 & 2.00 & 1.31 & 1.00 & 3.00 \\
\hline$O P \_R I S K S$ & 700 & 2.00 & 1.00 & 2.22 & 0.00 & 4.00 \\
\hline FTSE 100 & 700 & 0.19 & 0.00 & 0.39 & 0.00 & 0.00 \\
\hline FTSE250 & 700 & 0.39 & 0.00 & 0.49 & 0.00 & 1.00 \\
\hline$S I Z E$ & 700 & 20.49 & 20.50 & 1.50 & 19.26 & 21.80 \\
\hline$S I$ & 700 & -0.01 & -0.00 & 0.02 & -0.02 & 0.00 \\
\hline$L O S S$ & 700 & 0.16 & 0.00 & 0.37 & 0.00 & 0.00 \\
\hline$B U S Y$ & 700 & 0.75 & 1.00 & 0.43 & 1.00 & 1.00 \\
\hline$M B$ & 700 & 2.41 & 1.84 & 1.78 & 1.03 & 3.43 \\
\hline ACQUISITION & 700 & 0.52 & 1.00 & 0.50 & 0.00 & 1.00 \\
\hline$A G E$ & 700 & 23.91 & 18.00 & 17.09 & 10.00 & 37.50 \\
\hline NBSEG & 700 & 3.98 & 4.03 & 1.17 & 3.09 & 4.77 \\
\hline SEO & 700 & 0.08 & 0.00 & 0.27 & 0.00 & 0.00 \\
\hline$E A R N \_V O L$ & 700 & 0.05 & 0.02 & 0.06 & 0.01 & 0.06 \\
\hline COMBINED_OP & 700 & 0.69 & 1.00 & 0.46 & 0.00 & 1.00 \\
\hline$E X P \_N U M C L T$ & 700 & 0.36 & 0.00 & 0.48 & 0.00 & 1.00 \\
\hline EXP_DOMINANCE & 700 & 0.33 & 0.00 & 0.47 & 0.00 & 1.00 \\
\hline LOGSIZE & 700 & 6.45 & 6.61 & 1.58 & 5.16 & 7.72 \\
\hline INST & 698 & 5.49 & 5.50 & 2.87 & 3.00 & 8.00 \\
\hline$R D$ & 700 & 0.02 & 0.00 & 0.03 & 0.00 & 0.02 \\
\hline CROSS_LIST & 700 & 0.05 & 0.00 & 0.23 & 0.00 & 0.00 \\
\hline NEGATIVE & 700 & 1.24 & 1.21 & 0.58 & 0.97 & 1.70 \\
\hline POSITIVE & 700 & 0.25 & 0.25 & 0.08 & 0.16 & 0.30 \\
\hline UNCERTAIN & 700 & 0.87 & 0.80 & 0.44 & 0.44 & 1.29 \\
\hline LONDON & 700 & 0.55 & 1.00 & 0.50 & 0.00 & 1.00 \\
\hline GOING_CONCERN & 700 & 0.02 & 0.00 & 0.15 & 0.00 & 0.00 \\
\hline
\end{tabular}

Note: All continuous variables are winsorized at the $1^{\text {st }}$ and $99^{\text {th }}$ percentiles 
TABLE 3

Univariate Statistics

(Mean Values)

\begin{tabular}{|c|c|c|c|c|c|}
\hline & \multicolumn{3}{|c|}{$\begin{array}{c}\text { Pre }-I S A 700 \\
(N E W O P I N I O N=0)\end{array}$} & \multirow[t]{2}{*}{$\begin{array}{c}\text { Post-ISA } 700 \\
(N E W O P I N I O N=1)\end{array}$} & \multirow[t]{2}{*}{$\begin{array}{c}\text { Mean } \\
\text { Difference }\end{array}$} \\
\hline & $\mathrm{N}$ & & $\mathrm{N}$ & & \\
\hline$F O G$ & 350 & 29.76 & 350 & 24.93 & $-4.83 * * *$ \\
\hline NEGATIVE & 350 & 0.80 & 350 & 1.67 & $0.87 * * *$ \\
\hline POSITIVE & 350 & 0.23 & 350 & 0.27 & $0.04 * * *$ \\
\hline UNCERTAIN & 350 & 0.49 & 350 & 1.26 & $0.77 * * *$ \\
\hline FOLLOWING & 310 & 10.84 & 310 & 10.57 & -0.27 \\
\hline DISPERSION & 283 & 0.31 & 283 & 0.28 & -0.03 \\
\hline LOGFEES & 350 & 12.99 & 350 & 13.01 & 0.02 \\
\hline$R A W_{-} F E E S$ (millions) & 350 & 0.76 & 350 & 0.78 & 0.02 \\
\hline$B I G N$ & 350 & 0.93 & 350 & 0.93 & 0.00 \\
\hline$O P \_P A G E S$ & 350 & 1.23 & 350 & 3.34 & $2.11 * * *$ \\
\hline$O P \_R I S K S$ & 350 & 0.03 & 350 & 3.97 & $3.94 * * *$ \\
\hline COMBINED_OP & 350 & 0.61 & 350 & 0.77 & $0.16 * * *$ \\
\hline
\end{tabular}

$* * * p<0.01, * * p<0.05, * \mathrm{p}<0.10$ 


\section{TABLE 4}

\section{ISA 700 Auditor Reporting Requirement and Audit Report Readability}

This table examines the association between the ISA 700 auditor reporting requirement and audit report readability. Variable definitions are located in Appendix A. T-values are in the parentheses. $* * * p<0.01$, $* * p<0.05, * \mathrm{p}<0.10$; represents one-tailed $\mathrm{p}$-value significance for signed predictions and two-tailed $\mathrm{p}$ value significance for unsigned predictions. Industry effects are included. Standard errors clustered by firm.

(1)

NEWOPINION

SIZE

MB

AGE

SI

EARN_VOL

NBSEG

ACQUISITION

SEO

BIGN

COMBINED_OP

Constant

Industry FE?

$R^{2}$

N
29.79

(19.70)***

\begin{tabular}{c}
\hline $\mathrm{DV}=\mathrm{FOG}$ \\
\hline-4.99 \\
$(-30.55)^{* * *}$ \\
-0.08 \\
$(-1.01)$ \\
-0.03 \\
$(-0.58)$ \\
-0.00 \\
$(-1.05)$ \\
-0.63 \\
$(-0.14)$ \\
-2.89 \\
$(-1.57)$ \\
0.01 \\
$(0.14)$ \\
0.03 \\
$(0.19)$ \\
-0.22 \\
$(-1.02)$ \\
0.76 \\
$(1.81)^{*}$ \\
1.08 \\
$(6.40)^{* * *}$ \\
\\
29.79 \\
$(19.70)^{* * *}$ \\
\\
Yes \\
$72.58 \%$ \\
\\
\\
\\
\\
\\
\\
\\
\end{tabular}


TABLE 5

ISA 700 Auditor Reporting Requirement and Audit Report Tone Analysis

This table examines the association between the ISA 700 auditor reporting requirement and audit report tone. Variable definitions are located in Appendix A. T-values are in parentheses. $* * * p<0.01, * * \mathrm{p}<0.05$, $* \mathrm{p}<0.10$; represents one-tailed $\mathrm{p}$-value significance for signed predictions and two-tailed $\mathrm{p}$-value significance for unsigned predictions. Industry effects are included. Standard errors clustered by firm.

\begin{tabular}{|c|c|c|c|c|}
\hline & (1) & (2) & (3) & (4) \\
\hline & $\begin{array}{c}\text { DV }= \\
\text { NEGATIVE }\end{array}$ & $\begin{array}{c}\mathrm{DV}= \\
\text { POSITIVE }\end{array}$ & $\begin{array}{c}\mathrm{DV}= \\
\text { UNCERTAIN }\end{array}$ & $\begin{array}{c}\mathrm{DV}= \\
\text { COMBINED } \\
\text { TONE }\end{array}$ \\
\hline NEWOPINION & $\begin{array}{c}0.92 \\
(36.50)^{* * *}\end{array}$ & $\begin{array}{l}0.04 \\
(7.12)^{* * *}\end{array}$ & $\begin{array}{c}0.78 \\
(51.68)^{* * *}\end{array}$ & $\begin{array}{c}1.77 \\
(46.16)^{* * *}\end{array}$ \\
\hline SIZE & $\begin{array}{l}-0.00 \\
(-0.02)\end{array}$ & $\begin{array}{l}0.01 \\
(2.10)^{* *}\end{array}$ & $\begin{array}{l}0.03 \\
(3.47)^{* * * *}\end{array}$ & $\begin{array}{l}0.04 \\
(1.93)^{*}\end{array}$ \\
\hline MB & $\begin{array}{c}-0.00 \\
(-0.39)\end{array}$ & $\begin{array}{c}0.00 \\
(1.08)\end{array}$ & $\begin{array}{l}-0.00 \\
(-0.49)\end{array}$ & $\begin{array}{l}-0.00 \\
(-0.31)\end{array}$ \\
\hline AGE & $\begin{array}{c}0.00 \\
(1.25)\end{array}$ & $\begin{array}{c}0.00 \\
(1.02)\end{array}$ & $\begin{array}{l}0.00 \\
(1.66)^{*}\end{array}$ & $\begin{array}{c}0.00 \\
(1.56)\end{array}$ \\
\hline SI & $\begin{array}{l}-2.34 \\
(-3.06) * * *\end{array}$ & $\begin{array}{c}0.19 \\
(1.07)\end{array}$ & $\begin{array}{l}-1.36 \\
(-2.70)^{* * *}\end{array}$ & $\begin{array}{l}-3.14 \\
(-2.73)^{* * *}\end{array}$ \\
\hline EARN_VOL & $\begin{array}{c}0.24 \\
(0.70)\end{array}$ & $\begin{array}{l}-0.19 \\
(-2.18)^{* *}\end{array}$ & $\begin{array}{l}-0.37 \\
(-2.01)^{* *}\end{array}$ & $\begin{array}{c}-0.29 \\
(-0.63)\end{array}$ \\
\hline NBSEG & $\begin{array}{l}-0.03 \\
(-2.16)^{* *}\end{array}$ & $\begin{array}{c}-0.01 \\
(-1.55)\end{array}$ & $\begin{array}{l}-0.01 \\
(-0.96)\end{array}$ & $\begin{array}{l}-0.05 \\
(-2.23)^{* *}\end{array}$ \\
\hline ACQUISITION & $\begin{array}{c}0.00 \\
(0.04)\end{array}$ & $\begin{array}{c}-0.00 \\
(-0.16)\end{array}$ & $\begin{array}{c}0.02 \\
(1.17)\end{array}$ & $\begin{array}{c}0.02 \\
(0.37)\end{array}$ \\
\hline SEO & $\begin{array}{c}-0.01 \\
(-0.21)\end{array}$ & $\begin{array}{c}-0.00 \\
(-0.46)\end{array}$ & $\begin{array}{c}0.01 \\
(0.46)\end{array}$ & $\begin{array}{l}-0.01 \\
(-0.11)\end{array}$ \\
\hline BIGN & $\begin{array}{l}0.21 \\
(2.89)^{* * *}\end{array}$ & $\begin{array}{l}0.04 \\
(3.40)^{* * *}\end{array}$ & $\begin{array}{c}0.05 \\
(1.35)\end{array}$ & $\begin{array}{l}0.31 \\
(3.16)^{* * *}\end{array}$ \\
\hline COMBINED_OP & $\begin{array}{c}-0.32 \\
(-11.46)^{* * *}\end{array}$ & $\begin{array}{l}-0.04 \\
(-6.52)^{* * *}\end{array}$ & $\begin{array}{l}-0.07 \\
(-4.17)^{* * *}\end{array}$ & $\begin{array}{c}-0.44 \\
(-10.85)^{* * * *}\end{array}$ \\
\hline Constant & $\begin{array}{l}0.86 \\
(2.95)^{* * * *}\end{array}$ & $\begin{array}{l}0.09 \\
(1.32)\end{array}$ & $\begin{array}{c}-0.12 \\
(-0.72)\end{array}$ & $\begin{array}{l}0.78 \\
(1.97)^{* *}\end{array}$ \\
\hline Industry FE? & Yes & Yes & Yes & Yes \\
\hline$R^{2}$ & $67.79 \%$ & $15.38 \%$ & $80.13 \%$ & $77.65 \%$ \\
\hline$N$ & 700 & 700 & 700 & 700 \\
\hline
\end{tabular}


TABLE 6

ISA 700, Audit Report Readability, and Analyst Following

This table examines the association between: 1) ISA 700 and analyst following; and 2) audit report readability and analyst following. Variable definitions are located in Appendix A. T-values are in parentheses. $* * * \mathrm{p}<0.01$, $* * \mathrm{p}<0.05$, $* \mathrm{p}<0.10$; represents one-tailed $\mathrm{p}$-value significance for signed predictions and two-tailed p-value significance for unsigned predictions. Industry effects are included. Standard errors clustered by firm.

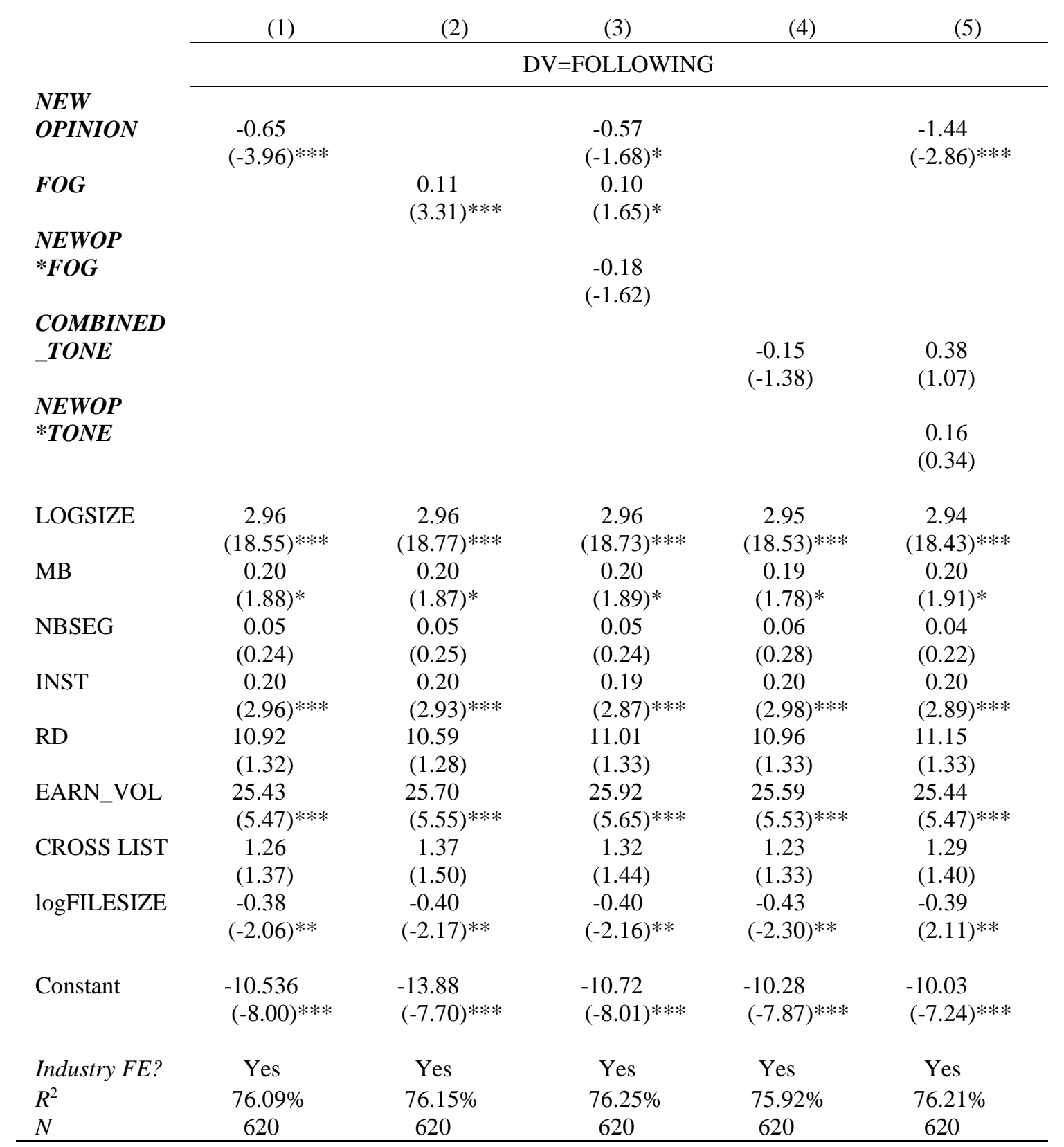


TABLE 7

ISA 700, Audit Report Readability, and Analyst Forecast Dispersion

This table examines the association between: 1) ISA 700 and analyst forecast dispersion; and 2) audit report readability and analyst forecast dispersion. Variable definitions are located in Appendix A. Tvalues are in parentheses. $* * * \mathrm{p}<0.01, * * \mathrm{p}<0.05, * \mathrm{p}<0.10$; represents one-tailed $\mathrm{p}$-value significance for signed predictions and two-tailed p-value significance for unsigned predictions. Industry effects are included. Standard errors clustered by firm.

(1)

DV=DISPERSION

\begin{tabular}{|c|c|c|c|c|c|}
\hline \multicolumn{6}{|l|}{$N E W$} \\
\hline \multirow{2}{*}{ OPINION } & -0.02 & & 0.00 & & -0.03 \\
\hline & $(-1.66)^{*}$ & & $(0.16)$ & & $(-0.78)$ \\
\hline \multirow[t]{2}{*}{$F O G$} & & 0.01 & 0.01 & & \\
\hline & & $(2.28)^{* *}$ & $(2.26)^{* *}$ & & \\
\hline \multicolumn{6}{|l|}{ NEWOP } \\
\hline \multirow{2}{*}{$* F O G$} & & & -0.02 & & \\
\hline & & & $(-1.87)^{*}$ & & \\
\hline \multicolumn{6}{|l|}{ COMBINED } \\
\hline \multirow{2}{*}{ _TONE } & & & & -0.01 & -0.00 \\
\hline & & & & $(-1.18)$ & $(-0.20)$ \\
\hline \multicolumn{6}{|l|}{ NEWOP } \\
\hline \multirow{2}{*}{$* T O N E$} & & & & & 0.02 \\
\hline & & & & & $(0.47)$ \\
\hline \multirow[t]{2}{*}{ LOGSIZE } & -0.02 & -0.02 & -0.02 & -0.02 & -0.02 \\
\hline & $(-1.60)$ & $(-1.57)$ & $(-1.55)$ & $(-1.60)$ & $(-1.59)$ \\
\hline \multirow[t]{2}{*}{ MB } & -0.01 & -0.01 & -0.01 & -0.01 & -0.01 \\
\hline & $(-0.93)$ & $(-0.91)$ & $(-0.93)$ & $(-0.96)$ & $(-0.93)$ \\
\hline \multirow[t]{2}{*}{ NBSEG } & 0.02 & 0.02 & 0.02 & 0.02 & 0.02 \\
\hline & $(1.67)^{*}$ & $(1.70)^{*}$ & $(1.76)^{*}$ & $(1.69)^{*}$ & $(1.65)^{*}$ \\
\hline \multirow[t]{2}{*}{ INST } & 0.01 & 0.01 & 0.01 & 0.01 & 0.01 \\
\hline & $(1.82)^{*}$ & $(1.81)^{*}$ & $(1.69)^{*}$ & (1.83) & $(1.80)$ \\
\hline \multirow[t]{2}{*}{ RD } & 1.45 & 1.43 & 1.44 & 1.44 & 1.44 \\
\hline & $(2.12)^{* *}$ & $(2.10)^{* *}$ & $(2.13)^{* *}$ & $(2.11)^{* *}$ & $(2.10)^{* *}$ \\
\hline \multirow[t]{2}{*}{ EARN_VOL } & -0.25 & -0.23 & -0.20 & -0.25 & -0.25 \\
\hline & $(-0.86)$ & $(-0.80)$ & $(-0.69)$ & $(-0.84)$ & $(-0.85)$ \\
\hline \multirow[t]{2}{*}{ logFILESIZE } & 0.00 & 0.00 & -0.00 & 0.00 & 0.00 \\
\hline & $(0.12)$ & $(0.12)$ & $(-0.06)$ & $(0.07)$ & $(0.13)$ \\
\hline \multirow[t]{2}{*}{ Constant } & 0.35 & 0.18 & 0.32 & 0.36 & 0.35 \\
\hline & $(2.95)^{* * *}$ & (1.26) & $(2.78)^{* * *}$ & $(3.14)^{* * *}$ & $(2.78)^{* * *}$ \\
\hline Industry FE? & Yes & Yes & Yes & Yes & Yes \\
\hline$R^{2}$ & $12.70 \%$ & $12.99 \%$ & $13.50 \%$ & $12.63 \%$ & $12.73 \%$ \\
\hline$N$ & 566 & 566 & 566 & 566 & 566 \\
\hline
\end{tabular}


TABLE 8

Audit Report Readability and Auditor Characteristics

This table examines the association between the ISA 700 auditor reporting requirement and auditor characteristics. Variable definitions are located in Appendix A. T-values are in the parentheses. *** $\mathrm{p}<0.01, * * \mathrm{p}<0.05, * \mathrm{p}<0.10$; represents one-tailed $\mathrm{p}$-value significance for signed predictions and twotailed $\mathrm{p}$-value significance for unsigned predictions. Industry effects are included. Standard errors clustered by firm.

\begin{tabular}{|c|c|c|c|c|c|c|}
\hline \multirow{3}{*}{ BIGN } & (1) & (2) & (3) & (4) & (5) & (6) \\
\hline & \multicolumn{6}{|c|}{$\mathrm{DV}=\mathrm{FOG}$} \\
\hline & $\begin{array}{l}-1.23 \\
(-2.54)^{* *}\end{array}$ & & & & $\begin{array}{l}-0.96 \\
(-1.94)^{*}\end{array}$ & $\begin{array}{l}-0.89 \\
(-1.75)^{*}\end{array}$ \\
\hline OFFICE_SIZE & & $\begin{array}{l}-0.01 \\
(-2.10)^{* *}\end{array}$ & & & $\begin{array}{l}-0.01 \\
(-1.34)\end{array}$ & $\begin{array}{l}-0.01 \\
(-1.36)\end{array}$ \\
\hline$E X P_{-}$ & & & & & & \\
\hline NUMCLT & & & $\begin{array}{l}-0.61 \\
(-3.17) * * *\end{array}$ & & $\begin{array}{c}-0.47 \\
(-2.42)^{* *}\end{array}$ & \\
\hline$E X P_{-}$ & & & & & & \\
\hline DOMINANCE & & & & $\begin{array}{l}-0.89 \\
(-4.55)^{* * * *}\end{array}$ & & $\begin{array}{l}-0.77 \\
(-3.83) * * *\end{array}$ \\
\hline SIZE & $\begin{array}{c}-0.10 \\
(-0.87)\end{array}$ & $\begin{array}{c}-0.14 \\
(-1.23)\end{array}$ & $\begin{array}{c}-0.17 \\
(-1.49)\end{array}$ & $\begin{array}{l}-0.16 \\
(-1.41)\end{array}$ & $\begin{array}{c}-0.09 \\
(-0.81)\end{array}$ & $\begin{array}{c}-0.09 \\
(-0.78)\end{array}$ \\
\hline MB & $\begin{array}{c}-0.01 \\
(-0.19)\end{array}$ & $\begin{array}{c}-0.03 \\
(-0.54)\end{array}$ & $\begin{array}{l}-0.02 \\
(-0.35)\end{array}$ & $\begin{array}{c}-0.02 \\
(-0.31)\end{array}$ & $\begin{array}{l}-0.00 \\
(-0.04)\end{array}$ & $\begin{array}{c}0.00 \\
(0.00)\end{array}$ \\
\hline AGE & $\begin{array}{c}-0.01 \\
(-0.98)\end{array}$ & $\begin{array}{c}-0.00 \\
(-0.82)\end{array}$ & $\begin{array}{l}-0.01 \\
(-1.04)\end{array}$ & $\begin{array}{c}-0.01 \\
(-1.24)\end{array}$ & $\begin{array}{l}-0.01 \\
(-1.02)\end{array}$ & $\begin{array}{l}-0.01 \\
(-1.21)\end{array}$ \\
\hline SI & $\begin{array}{c}2.60 \\
(0.44)\end{array}$ & $\begin{array}{l}3.15 \\
(0.54)\end{array}$ & $\begin{array}{l}5.30 \\
(0.89)\end{array}$ & $\begin{array}{c}5.86 \\
(0.99)\end{array}$ & $\begin{array}{c}3.76 \\
(0.64)\end{array}$ & $\begin{array}{c}4.47 \\
(0.76)\end{array}$ \\
\hline EARN_VOL & $\begin{array}{c}2.45 \\
(1.06)\end{array}$ & $\begin{array}{l}3.60 \\
(1.61)\end{array}$ & $\begin{array}{l}3.80 \\
(1.68)^{*}\end{array}$ & $\begin{array}{l}3.78 \\
(1.68)^{*}\end{array}$ & $\begin{array}{c}3.13 \\
(1.35)\end{array}$ & $\begin{array}{c}3.21 \\
(1.39)\end{array}$ \\
\hline NBSEG & $\begin{array}{c}0.05 \\
(0.48)\end{array}$ & $\begin{array}{c}0.04 \\
(0.35)\end{array}$ & $\begin{array}{c}0.03 \\
(0.30)\end{array}$ & $\begin{array}{c}0.03 \\
(0.28)\end{array}$ & $\begin{array}{c}0.06 \\
(0.59)\end{array}$ & $\begin{array}{c}0.06 \\
(0.56)\end{array}$ \\
\hline ACQUISITION & $\begin{array}{c}0.07 \\
(0.31)\end{array}$ & $\begin{array}{c}0.10 \\
(0.42)\end{array}$ & $\begin{array}{c}0.08 \\
(0.34)\end{array}$ & $\begin{array}{c}0.09 \\
(0.37)\end{array}$ & $\begin{array}{c}0.10 \\
(0.46)\end{array}$ & $\begin{array}{c}0.11 \\
(0.49)\end{array}$ \\
\hline SEO & $\begin{array}{c}-0.25 \\
(-0.96)\end{array}$ & $\begin{array}{l}-0.24 \\
(-0.94)\end{array}$ & $\begin{array}{l}-0.39 \\
(-1.40)\end{array}$ & $\begin{array}{c}-0.44 \\
(-1.60)\end{array}$ & $\begin{array}{l}-0.33 \\
(-1.20)\end{array}$ & $\begin{array}{l}-0.390 \\
(-1.44)\end{array}$ \\
\hline $\begin{array}{l}\text { COMBINED } \\
\text { _OP }\end{array}$ & $\begin{array}{c}0.23 \\
(0.82)\end{array}$ & $\begin{array}{c}0.29 \\
(1.06)\end{array}$ & $\begin{array}{c}0.27 \\
(1.02)\end{array}$ & $\begin{array}{c}0.22 \\
(0.83)\end{array}$ & $\begin{array}{c}0.28 \\
(1.06)\end{array}$ & $\begin{array}{c}0.23 \\
(0.91)\end{array}$ \\
\hline Constant & $\begin{array}{l}27.66 \\
(12.72) * * *\end{array}$ & $\begin{array}{c}27.56 \\
(12.70)^{* * *}\end{array}$ & $\begin{array}{c}28.30 \\
(12.74)^{* * * *}\end{array}$ & $\begin{array}{c}28.29 \\
(12.78)^{* * *}\end{array}$ & $\begin{array}{c}27.48 \\
(12.49)^{* * *}\end{array}$ & $\begin{array}{c}27.51 \\
(12.53)^{* * *}\end{array}$ \\
\hline Industry FE? & Yes & Yes & Yes & Yes & Yes & Yes \\
\hline$R^{2}$ & $6.46 \%$ & $4.94 \%$ & $6.40 \%$ & $8.63 \%$ & $8.52 \%$ & $10.53 \%$ \\
\hline$N$ & 350 & 350 & 350 & 350 & 350 & 350 \\
\hline
\end{tabular}


TABLE 9

ISA 700 Auditor Report Readability and Audit Firms

This table examines the association between the ISA 700 auditor reporting readability and audit firms. Variable definitions are located in Appendix A. T-values are in the parentheses. $* * * p<0.01, * * p<0.05$, $* \mathrm{p}<0.10$; represents one-tailed $\mathrm{p}$-value significance for signed predictions and two-tailed $\mathrm{p}$-value significance for unsigned predictions. Industry effects are included. Standard errors clustered by firm.

(1)

(2)

NEWOPINION

EY

NEWOP*EY

SIZE

MB

AGE

SI

EARN_VOL

NBSEG

ACQUISITION

SEO

COMBINED_OP

Constant

Industry FE?

$R^{2}$

N

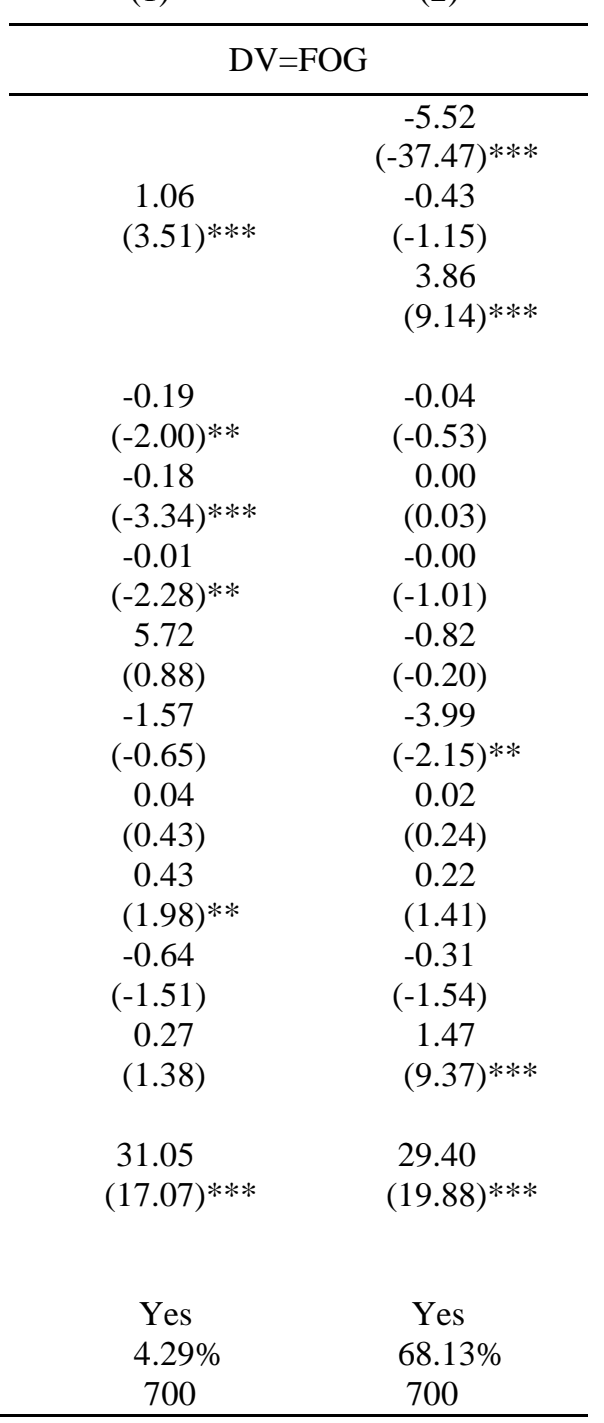


TABLE 10

Alternative Tone Measures

This table examines the association between the ISA 700 auditor reporting readability and alternative tone measures. Variable definitions are located in Appendix A. T-values are in the parentheses. $* * * p<0.01, * * p<0.05,{ }^{*} \mathrm{p}<0.10$; represents one-tailed $\mathrm{p}$-value significance for signed predictions and two-tailed p-value significance for unsigned predictions. Industry effects are included. Standard errors clustered by firm.

Panel A: Univariate Analysis (Mean Values)

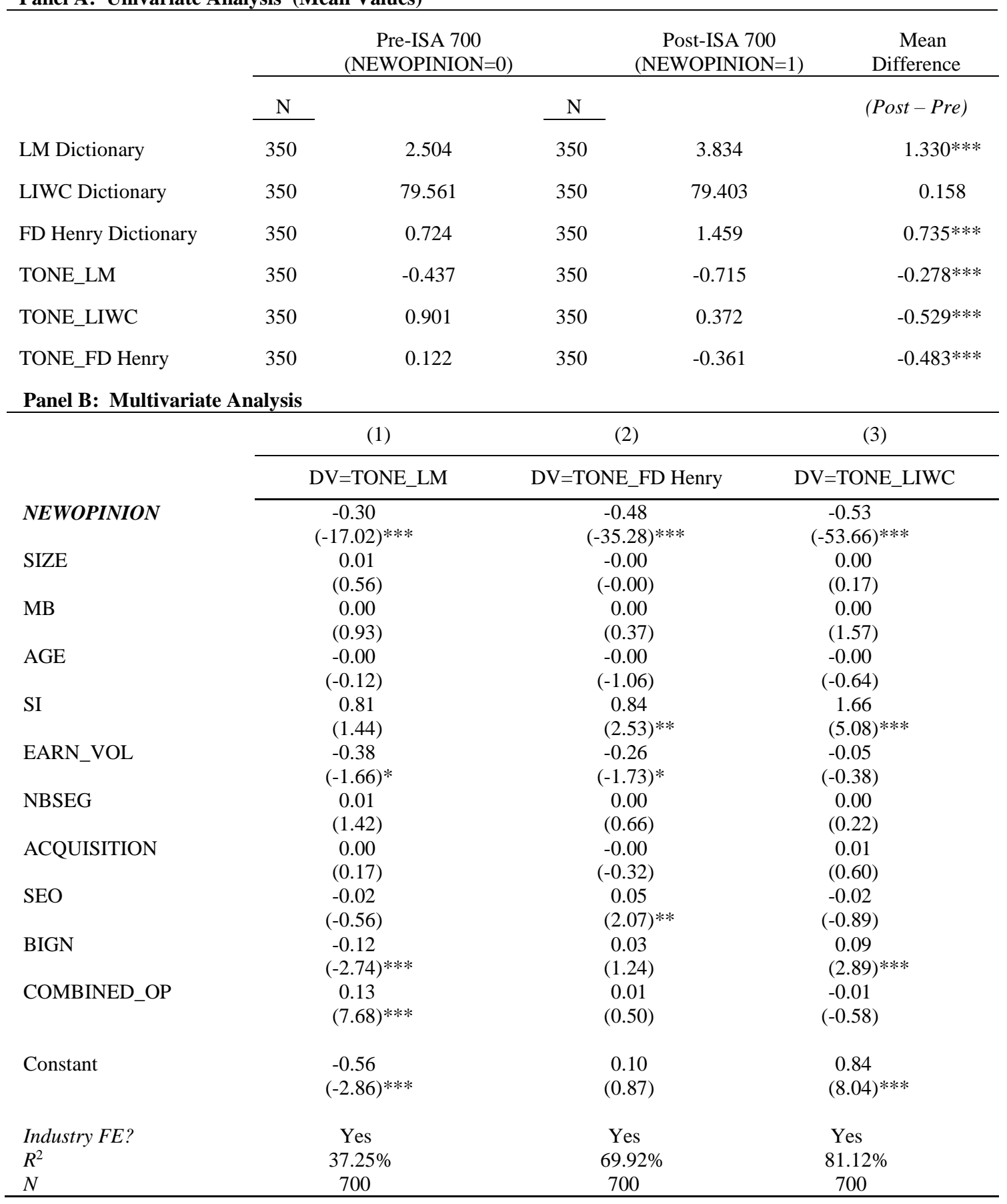




\section{APPENDIX C}

TWENTY MOST FREQUENT WORDS OCCURRING IN THE PRE AND POST ISA 700 AUDIT REPORTS FROM THE LOUGHRAN AND MCDONALD NEGATIVE AND HENRY FINANCIAL DISCLOSURE WORD LISTS

\begin{tabular}{|c|c|c|c|c|c|}
\hline \multicolumn{6}{|c|}{ Panel A: Loughran and McDonald Negative Word List } \\
\hline \multicolumn{3}{|c|}{ Pre-ISA 700 Audit Reports } & \multicolumn{3}{|c|}{ Post-ISA 700 Audit Reports } \\
\hline Rank & Word & $\begin{array}{c}\text { \% of Fin- } \\
\text { Neg Word } \\
\text { Count }\end{array}$ & Rank & Word & $\begin{array}{l}\text { \% of Fin- } \\
\text { Neg Word } \\
\text { Count }\end{array}$ \\
\hline 1 & inconsistencies & $21.56 \%$ & 1 & misstatement & $10.96 \%$ \\
\hline 2 & concern & $17.07 \%$ & 2 & concern & $10.15 \%$ \\
\hline 3 & misstatement & $11.30 \%$ & 3 & misstatements & $7.15 \%$ \\
\hline 4 & disclosed & $11.17 \%$ & 4 & impairment & $7.14 \%$ \\
\hline 5 & error & $11.08 \%$ & 5 & inconsistent & $6.26 \%$ \\
\hline 6 & fraud & $11.08 \%$ & 6 & inconsistencies & $5.95 \%$ \\
\hline 7 & misstatements & $10.85 \%$ & 7 & fraud & $4.53 \%$ \\
\hline 8 & loss & $2.09 \%$ & 8 & challenged & $4.14 \%$ \\
\hline 9 & inconsistent & $0.54 \%$ & 9 & disclosed & $3.97 \%$ \\
\hline 10 & incorrect & $0.45 \%$ & 10 & incorrect & $3.79 \%$ \\
\hline 11 & unable & $0.45 \%$ & 11 & misleading & $3.26 \%$ \\
\hline 12 & doubt & $0.36 \%$ & 12 & against & $3.21 \%$ \\
\hline 13 & uncorrected & $0.18 \%$ & 13 & error & $2.21 \%$ \\
\hline 14 & critical & $0.14 \%$ & 14 & uncorrected & $1.46 \%$ \\
\hline 15 & redress & $0.14 \%$ & 15 & claims & $1.28 \%$ \\
\hline 16 & undetected & $0.14 \%$ & 16 & loss & $1.27 \%$ \\
\hline 17 & concerned & $0.09 \%$ & 17 & challenging & $1.13 \%$ \\
\hline 18 & impairment & $0.09 \%$ & 18 & discloses & $1.07 \%$ \\
\hline 19 & misleading & $0.09 \%$ & 19 & inappropriate & $0.96 \%$ \\
\hline 20 & negligence & $0.09 \%$ & 20 & losses & $0.84 \%$ \\
\hline
\end{tabular}


Panel B: Henry Financial Disclosure (FD) Word List

\begin{tabular}{|c|c|c|c|c|c|}
\hline \multicolumn{3}{|c|}{ Pre-ISA 700 Audit Reports } & \multicolumn{3}{|c|}{ Post-ISA 700 Audit Reports } \\
\hline Rank & Word & $\begin{array}{c}\% \text { of } \\
\text { Henry FD } \\
\text { Word } \\
\text { Count }\end{array}$ & Rank & Word & $\begin{array}{c}\% \text { of } \\
\text { Henry FD } \\
\text { Word } \\
\text { Count }\end{array}$ \\
\hline 1 & under & $40.86 \%$ & 1 & risk & $18.22 \%$ \\
\hline 2 & certain & $26.40 \%$ & 2 & under & $15.76 \%$ \\
\hline 3 & more & $20.92 \%$ & 3 & risks & $12.54 \%$ \\
\hline 4 & risk & $7.95 \%$ & 4 & certain & $6.83 \%$ \\
\hline 5 & uncertainty & $0.81 \%$ & 5 & below & $5.81 \%$ \\
\hline 6 & risks & $0.46 \%$ & 6 & above & $5.79 \%$ \\
\hline 7 & below & $0.40 \%$ & 7 & challenged & $4.98 \%$ \\
\hline 8 & uncertainties & $0.40 \%$ & 8 & more & $3.97 \%$ \\
\hline 9 & low & $0.29 \%$ & 9 & growth & $3.36 \%$ \\
\hline 10 & above & $0.23 \%$ & 10 & greatest & $2.29 \%$ \\
\hline 11 & achieve & $0.23 \%$ & 11 & uncertain & $1.79 \%$ \\
\hline 12 & successful & $0.23 \%$ & 12 & least & $1.56 \%$ \\
\hline 13 & exceeds & $0.12 \%$ & 13 & uncertainty & $1.38 \%$ \\
\hline 14 & greatest & $0.12 \%$ & 14 & most & $1.37 \%$ \\
\hline 15 & uncertain & $0.12 \%$ & 15 & challenging & $1.36 \%$ \\
\hline 16 & challenged & $0.06 \%$ & 16 & lower & $1.27 \%$ \\
\hline 17 & challenging & $0.06 \%$ & 17 & uncertainties & $0.95 \%$ \\
\hline 18 & exceed & $0.06 \%$ & 18 & challenge & $0.86 \%$ \\
\hline 19 & exceeded & $0.06 \%$ & 19 & achieve & $0.70 \%$ \\
\hline 20 & expansion & $0.06 \%$ & 20 & exceed & $0.57 \%$ \\
\hline
\end{tabular}

